\title{
Human Gut-Associated Natural Killer Cells in Health and Disease
}

\begin{abstract}
Alessandro Poggi ${ }^{1 *}$, Roberto Benelli ${ }^{2}$, Roberta Venè ${ }^{1}$, Delfina Costa ${ }^{1}$, Nicoletta Ferrari ${ }^{1}$, Francesca Tosetti ${ }^{1}$ and Maria Raffaella Zocchi ${ }^{3}$

${ }^{1}$ Molecular Oncology and Angiogenesis Unit, IRCCS Ospedale Policlinico San Martino, Genoa, Italy, ${ }^{2}$ Immunology Unit, IRCCS Ospedale Policlinico San Martino, Genoa, Italy, ${ }^{3}$ Division of Immunology, Transplantation and Infectious Diseases, IRCCS San Raffaele Scientific Institute, Milan, Italy
\end{abstract}

It is well established that natural killer (NK) cells are involved in both innate and adaptive immunity. Indeed, they can recognize molecules induced at the cell surface by stress signals and virus infections. The functions of NK cells in the gut are much more complex. Gut NK cells are not precisely organized in lymphoid aggregates but rather scattered in the epithelium or in the stroma, where they come in contact with a multitude of antigens derived from commensal or pathogenic microorganisms in addition to components of microbiota. Furthermore, NK cells in the bowel interact with several cell types, including epithelial cells, fibroblasts, macrophages, dendritic cells,

OPEN ACCESS

Edited by:

Michael A. Caligiuri, City of Hope National Medical Center United States

Reviewed by: Kamalakannan Rajasekaran, Genentech, Inc., United States William Garrow Kerr, Upstate Medical University, United States

*Correspondence:

Alessandro Poggi alessandro.poggi@hsanmartino.it

Specialty section: This article was submitted to NK and Innate Lymphoid Cell Biology, a section of the journal

Frontiers in Immunology

Received: 07 December 2018 Accepted: 15 April 2019 Published: 03 May 2019

Citation:

Poggi $A$, Benelli $R$, Venè $R$, Costa $D$, Ferrari N, Tosetti F and Zocchi MR (2019) Human Gut-Associated Natural Killer Cells in Health and Disease. Front. Immunol. 10:961. doi: 10.3389/fimmu.2019.00961 and $T$ lymphocytes, and contribute to the maintenance of immune homeostasis and development of efficient immune responses. NK cells have a key role in the response to intestinal bacterial infections, primarily through production of IFN $\gamma$, which can stimulate recruitment of additional NK cells from peripheral blood leading to amplification of the anti-bacterial immune response. Additionally, NK cells can have a role in the pathogenesis of gut autoimmune inflammatory bowel diseases (IBDs), such as Crohn's Disease and Ulcerative Colitis. These diseases are considered relevant to the generation of gastrointestinal malignancies. Indeed, the role of gut-associated NK cells in the immune response to bowel cancers is known. Thus, in the gut immune system, NK cells play a dual role, participating in both physiological and pathogenic processes. In this review, we will analyze the known functions of NK cells in the gut mucosa both in health and disease, focusing on the cross-talk among bowel microenvironment, epithelial barrier integrity, microbiota, and NK cells.

Keywords: gut-associated lymphoid tissues, natural killer cells, innate lymphoid cells, inflammatory bowel disease, colorectal carcinoma

\section{INTRODUCTION}

Gut associated lymphoid tissue (GALT), the part of the mucosa-associated lymphoid tissue (MALT) found along the gastrointestinal tract (GI), is essential to understanding the reaction of the host to external environment components (1-3). The content of gut lumen is continuously shucked and changed from the birth through adulthood and into old age. These changes strongly influence the type of immune response elicited and, consequently, may generate gut diseases (4-6). The GALT should be able to distinguish pathogenic and harmful organisms and antigens from those that are beneficial and not dangerous. The innate arm of the immune system can be considered the first 
line of defense against pathogenic microorganisms and their products; this arm can distinguish among microorganisms via pattern recognition receptors (PRRs) and Toll-like receptors (TLRs) present on macrophages, neutrophils, and dendritic cells (7-9). Also, natural killer (NK) cells can interact with gut microorganisms and influence and shape the adaptive $\mathrm{T}$ cellmediated immune response by acting on professional antigen presenting cells (APCs), such as dendritic cells (DCs). The phenotypic and functional features of gut associated NK cells are different from those that are typical of NK cells isolated from peripheral blood. In addition, gut lymphoid cells expressing some markers of NK cells, termed innate lymphoid cells (ILC) (10-12), appear to be involved in the regulation of gut mucosa homeostasis and in the generation of gut-associated lymphoid structures (13-19). On this basis, it is conceivable that NK cells (ILC1) and other subsets of ILC (ILC2 and ILC3) are not only involved in the control of healthy gut but also in the pathogenesis and evolution of gut diseases, including inflammatory bowel disease (IBD) and colorectal carcinoma (CRC) (20-23).

\section{NK CELL PHENOTYPIC AND FUNCTIONAL FEATURES IN HEALTHY GUT MUCOSA}

It is well-established that $\mathrm{NK}$ cells represent a group of $\mathrm{CD}^{-} \mathrm{CD}^{-} 6^{+}$innate immune cells (24). The majority of the findings on this topic is derived from studies on NK cells isolated from peripheral blood mononuclear cells (PBMCs) (24). Several comprehensive review articles have described the phenotypic and functional features of PB NK cells in detail (25-29). Briefly, PB NK cells can express the CD56 antigen at different intensities; indeed, CD56 $6^{\text {bright }}$ and CD56 ${ }^{\text {dull }}$ NK cells with predominant cytokine production or cytotoxic functions, respectively, have been identified. Several reports have stated that these two cell populations show a different functional role and a distinct array of receptors involved in the recognition of self-class I human histocompatibility antigens (HLA-I) (3033). It is not clear whether these two NK cell subsets derive from the same or different NK cell precursors and whether they display some plasticity, converting from one into the other (3436). Generally, lymphoid cells expressing CD56 isolated from the gut do not express CD16, i.e., the classical receptor for the crystallizable fragment of immunoglobulin (Fc $\gamma$ RIIIa) that is usually found on majority of PB NK cells (24). It has been reported that $\mathrm{CD}^{-} \mathrm{CD}^{+} 6^{+}$cells, like several other populations of tissue-resident innate cells (37-39), do not display a strong cytolytic activity if tested in vitro against conventional NK cell targets, but rather produce and release IFN $\gamma$ in vitro. According to studies of human and murine NK cells, the reduction or lack of cytotoxicity can be considered as a marker of immaturity in the main function displayed by NK cells (40-42). More correctly, $\mathrm{CD}^{-}{ }^{-} \mathrm{CD} 56^{+} \mathrm{CD}^{-} 6^{-}$mucosal $\mathrm{NK}$ cells could be considered lymphoid effectors that have a relevant role in the regulation of gut homeostasis (11). In line with this interpretation, the production of IL22 by GALT NK cells is essential for modulating expression of many genes in mucosal epithelial cells to favor epithelial cell survival and remodeling $(40,43)$. Of note, IL22 is produced by mucosal T lymphocytes, and it is conceivable that the imbalance between IL22 and IL17 is relevant to the generation of IBD (44). Importantly, GALT NK cells produce IL22 in response to IL23, but not to IL12. The more conventional NK cells found in PB or in the gut mucosa respond to IL12 by producing IFN $\gamma$ (45); these cytokines are involved in the response to infections (42-46). NK cells were found in lamina propria (LP) scattered in the middle of epithelial cells as intraepithelial lymphocytes (IELs), but not associated with lymphoid aggregates. This suggests that these cells do not participate as actively as $\mathrm{T}$ cells at antigen inductive sites present in the gut $(41,47)$.

\section{SMALL AND LARGE INTESTINE MUCOSA HISTOLOGY AND FUNCTION}

Herein, we focus mainly on the mucosa of the small intestine where the first interaction with lumen content takes place (Figures 1A,B). The surface epithelium and the underlying LP are arranged in villi and crypts, which give a velvetlike appearance to the mucosa. These structures amplify the absorbent surface of the gut and the crypts are surrounded and reinforced by a strong sheath of fibroblasts (FBs) (Figure 1B). Lymphoid and myeloid cells present within the gut mucosa can interact with epithelial absorptive cells (enterocytes), goblet cells that secrete ions, water and mucus, and a few endocrine cells that produce hormones and neuropeptides $(47,48)$. Goblet cells and enterocytes are derived from undifferentiated cells in a close cross-talk with pericryptal FBs and this relationship enhances the structural integrity and functional efficiency of the gut mucosa $(49,50)$. Importantly, LP penetrates the villi cores associated with blood vessels, connective tissue with different myeloid cells, smooth muscle cells, and blind-ended lacteals (Figures 1A-C, scheme in Figure 1D). The mucosa of large intestine is composed of the same cell types, but the structural organization is different; indeed, it is quite smooth without villi, and goblet cells are outnumbered by columnar absorptive cells. The principal protection for excluding undesired environmental factors, particularly harmful microorganisms, is provided by the GALT. GALT is composed of lymphoid aggregates (Figure 1A), mucosal LP lymphocytes, and intraepithelial lymphoid cells (Figure 1C) (51-53). Lymphoid aggregates increase in number along the small intestine and become confluent in the ileum, giving rise to Peyer's patches. These are un-encapsulated lymphoid structures, similar to lymph nodes (LN), with follicles composed of different cell types, including B, T, and accessory myeloid cells such as DCs $(53,54)$. Peyer's patches are important sites for the induction of the immune response, and the overlying epithelium contains multi-fenestrated or microfold cells ( $\mathrm{M}$ cells). $\mathrm{M}$ cells take up different molecules from the gut lumen that, through transcytosis, come in contact with the underlying lymphoid cells (55). In the LP there are plasma cells, which mainly produce IgA, that protect from bacterial invasion, macrophages, $\mathrm{T}$ and $\mathrm{B}$ lymphocytes, and polymorphs. Intraepithelial lymphocytes are concentrated in the small intestine, reaching a maximal ratio of 20 lymphocytes to 100 enterocytes in the jejunum and a lower ratio in the 
A

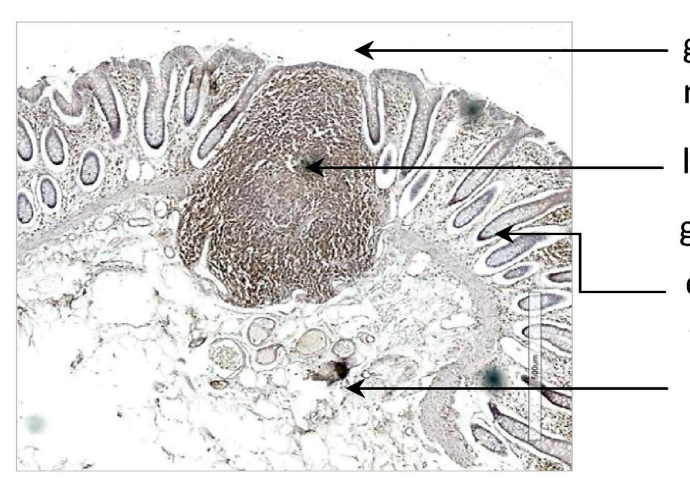

C

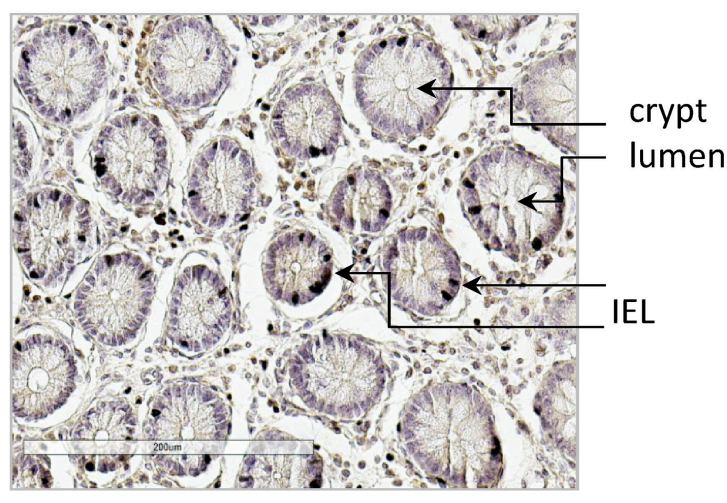

B

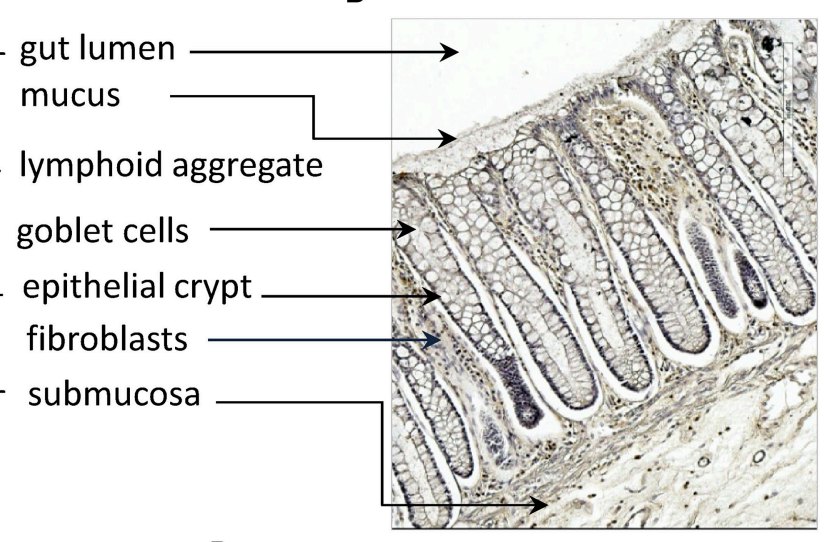

D

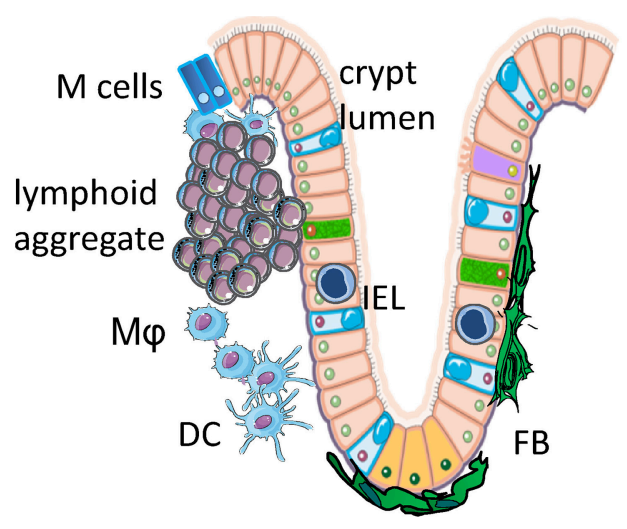

FIGURE 1 | Gut mucosa structure and gut-associated lymphoid tissue (GALT). (A-C) Longitudinal (A,B) and transversal (s) sections of healthy gut showing a lymphoid aggregate (A), identified by immunostaining with an anti-CD45RO monoclonal antibody, epithelial crypts (A-C), fibroblasts (B) and intraepithelial lymphocytes (IELs, C). (D) Schematic representation of the structure of gut mucosa and GALT. IELs, intraepithelial lymphocytes; M $\phi$, macrophages; DC, dendritic cells; FBs, fibroblasts. Arrows in (A-C) indicate the microscopic anatomy of gut mucosa, with the indicated cells and structures. Pink: enterocytes; yellow-orange: LGR5+ stem cells; cyan, goblet cells; purple, tuft cells; green, neuroendocrine cells; blue, M cells; IELs, intraepithelial lymphocytes.

ileum (56). While the small intestine, less colonized by bacteria, shows both isolated lymphoid follicles (ILFs) and specialized Peyer's patches, only ILFs are observed in the colon. These ILFs are in variable positions but arise whenever bacterial products permeate the epithelial barrier. The assembly of ILFs has only been extensively elucidated in mouse models, where it is linked to lymphoid tissue inducer (LTi) cells. These cells are a subpopulation of ILC3 and depend on retinoic acid receptorrelated orphan receptor gamma ( $\mathrm{ROR} \gamma \mathrm{t}$ ) expression. It is likely that colorectal ILFs in humans can also arise de novo, as their density and grade of maturation vary considerably in any given area of mucosa (57).

\section{NK CELL LOCALIZATION IN THE GUT}

Although NK cells are present in the gut, it remains to be defined if these cells are resident or derive from PB circulating NK cells. It is well established that leukocytes can extravasate in a specific area under the chemotactic stimuli and action of adhesion molecules (58-61). For example, the lymphocyte function associated antigen 1 (LFA1, CD11a/CD18) can interact with the intercellular adhesion molecule (ICAM)-1 expressed on endothelial cells, while the CD29/CD49d integrin (formerly very late antigen-4) binds to the vascular cell adhesion molecule (VCAM)-1 $(60,61)$. Of note, ICAM1 and VCAM1 are usually absent in healthy endothelial cells; however, the effect of inflammatory cytokines, such as IL1 $\beta$, IFN $\gamma$, and TNF $\alpha$, in tissues where an immune response takes place, results in strong upregulation of both ICAM1 and VCAM1 (60-62). PB NK cells can express several chemokine receptors (63), some of which are more abundant on CD56 bright than on CD56 ${ }^{\text {dull }}$ peripheral NK cells (64). It has been shown that ex vivo isolated NK cells bear CXCR1, CXCR3, and CXCR4, and contain subsets expressing CCR1, CCR4, CCR5, CCR6, CCR7, CCR9, CXCR5, and CXCR6. More precisely, CD56 ${ }^{\text {dull }}$ NK cells display a repertoire of chemokine receptors similar to that of neutrophils while this repertoire in CD56 $6^{\text {bright }}$ is most similar to that of T-helper (Th) 1 cells. These findings suggest that the CD56 $6^{\text {dull }}$ and the CD56 bright PBNK cells can migrate into tissues either at the beginning of the inflammatory reaction, which accompanies the immune response, or later (65). Of note, both $\mathrm{CD} 56^{\text {dull }}$ and $\mathrm{CD} 56^{\text {bright }}$ $\mathrm{PB}$ NK cells do not express the chemokine receptors needed 
TABLE 1 | Main surface molecules involved in NK cell function in the gut.

\begin{tabular}{|c|c|c|c|c|}
\hline Molecule & Family & Function & Ligands & Disease \\
\hline CD56/NCAM & Immunoglobulins & Cell-cell, cell-matrix adhesion & HSPGs $^{a}$, L1, NCAM & $\mathrm{CD}, \mathrm{CRC}$ \\
\hline CD57/GA3S & Carbohydrates & Adhesion, NK cell maturation & nd & $\mathrm{CRC}$ \\
\hline NKG2D/CD314 & C-type lectin & Recognition of infected/ transformed cells & $\mathrm{MICs}^{\mathrm{d}}, \mathrm{ULBPs}^{\mathrm{e}}$ & $C D, \cup C, C R C$ \\
\hline NKp30/CD337 & $\mathrm{NCR}^{f}$ & NK cell cytolytic activity & $\mathrm{BAG}^{9}, \mathrm{~B} 7-\mathrm{H} 6, \mathrm{Gal}-3$ & CRC \\
\hline KIRs/CD158 & Immunoglobulin like & Regulation of NK cell activity & HLA-A,-B, -C, -G & $\mathrm{CD}, \mathrm{CRC}$ \\
\hline
\end{tabular}

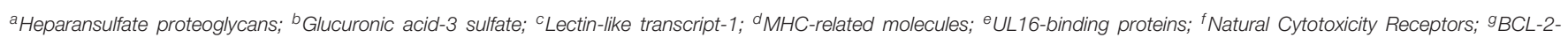
associated athanogene-6; ' ${ }^{h}$ Mixed-lineage leukemia-5; ${ }^{i}$ Hemagglutinin-A neuraminidase.

to home to the small intestine, such as CCR6 and CCR9 (6466). The lack of this homing capability would suggest that NK cells found in the gut are not derived from PB NK cells. However, some PB NK cells can express the CD161 antigen, also called NKRP1A $(67,68)$. This receptor is upregulated on NK cells upon stimulation with IL2 and, more importantly, it is expressed on majority of intestinal infiltrating lymphocytes $(68,69)$, including NK cells and some subsets of ILC $(2,5,10)$. It has been demonstrated that CD161 can function as an adhesion molecule involved in the transmigration of $\mathrm{PB} \mathrm{CD} 4^{+} \mathrm{T}$ cells through endothelial cells (70). It is still unknown whether CD161 also plays a role in the transendothelial migration of $\mathrm{PB} \mathrm{NK}$ cells, but it can be speculated that $\mathrm{CD} 161^{+} \mathrm{PB}$ NK cells localize in the tissue upon the cooperative involvement of LFA1, and engagement of the platelet endothelial cell adhesion molecule1 (PECAM1/CD31) on NK cells. Indeed, most NK cells express CD31, which allows a homophilic interaction with the CD31 present at the endothelial junction (71-74). CD161 might also regulate the speed of migration, as was shown for $\mathrm{CD} 4^{+} \mathrm{CD} 161^{+}$ $\mathrm{T}$ lymphocytes (70). The stromal derived factor 1 (SDF1, also named CXCL12), recognized by CXCR4, appears to favor tissue localization of NK cells, in particular of the CD56 ${ }^{\text {bright }}$ subset. However, NK cells, considered to be NKp46 ${ }^{+}$lymphocytes, are not so represented in the gut, although several chemokines are detectable in bowel diseases, including $\operatorname{CRC}(75,76)$. Collectively, these findings indicate that PB NK cells may localize into the gut, but their origin and the relative contribution of adhesion molecules and chemokine receptor-ligand interactions are yet to be established. Table 1 summarizes the main surface molecules, and their respective ligands, involved in gut NK cell function.

\section{INTESTINAL CRYPT NICHE AND IMMUNE SYSTEM CROSS-TALK AS THE FIRST LINE OF DEFENSE IN THE GUT}

Intestinal crypts have the highest rate of tissue turnover in the body (3-5 days), a process that is strongly influenced by the products (mainly short-chain fatty acids and lactate) of commensal bacteria, $(77,78)$. As the crypt contains the proliferating component of mucosa (3-5 stem cells in each crypt), providing for self-renewal of the entire tissue, its niche is organized to limit mechanical, infectious, and inflammatory damage (Figure 2). LGR5-positive stem cells are positioned at the bottom of the crypt, mixed with Paneth cells in the small intestine. Paneth cells secrete both trophic (wnt3) and antimicrobial factors (alpha-defensins, lysozyme, RegIII $\gamma$ lectin) (Figure 2B). Goblet cells, mixed with maturating enterocytes inside the crypt, produce mucus and release antimicrobial molecules, thereby creating the main barrier to microbial infection. Under normal conditions, the inner mucus layer is almost microbe-free, thus neither epithelial nor immune cells are in contact with danger signals (79-81). TLRs act as the main sensors for pathogen invasion in intestinal epithelial cells (IECs). Most TLRs are localized in the basolateral membrane of enterocytes, although TLR2 and 9 are also expressed on the luminal surface (Figure 2A) (82-84). TLRs mediate enterocytedriven reactions against viral and bacterial attacks. On the contrary, tuft cells which are rare, are specialized cells that act as sensors for parasites. When an infection occurs, tuft cells induce ILC2 activation and expansion by production of IL25. In turn, ILC2 secrete IL13 causing tuft cell proliferation, amplifying the signal (Figure 2C). The tuft cell-ILC2 cross-talk determines a type 2 cytokine response, activating goblet cells, macrophages, eosinophils, and other effectors $(85,86)$.

The cytokines that have a primary role in gut homeostasis and damage are summarized in Table 2. These cytokines, produced by NK cells and ILC, are involved in the regulation of these cell types, of their function and in integrity of gut mucosa. IEC behavior is modulated by several inflammatory cytokines that can increase tight junction permeability (TNF $\alpha, \operatorname{IFN} \gamma, \operatorname{IL} 1 \beta$, IL6) (86), priming the immune system and triggering a chronic response against innocent targets. To counteract inflammation, IECs chronically release soluble IL1 $\beta$ receptor (sIL1RII) and thymic stromal lymphopoietin (TSLP), while inflammatory cytokines trigger TGF $\beta$ neosynthesis. Soluble IL1RII neutralizes IL1 $\beta$, while TSLP and TGF $\beta$ condition dendritic cells, promoting Th2 and regulatory $\mathrm{T}$ cell (Treg) differentiation. Interestingly, sIL1RII is strongly downregulated during the active phases of Crohn's disease (CD) (87-89). A third regulatory mechanism is represented by the autocrine IL10 loop, activated in IECs in response to IFN $\gamma$, which re-establishes the mucosal barrier and maintains immunotolerance and acts through IL10R (9092). Indeed, IL10 KO mice develop a gut permeability defect 


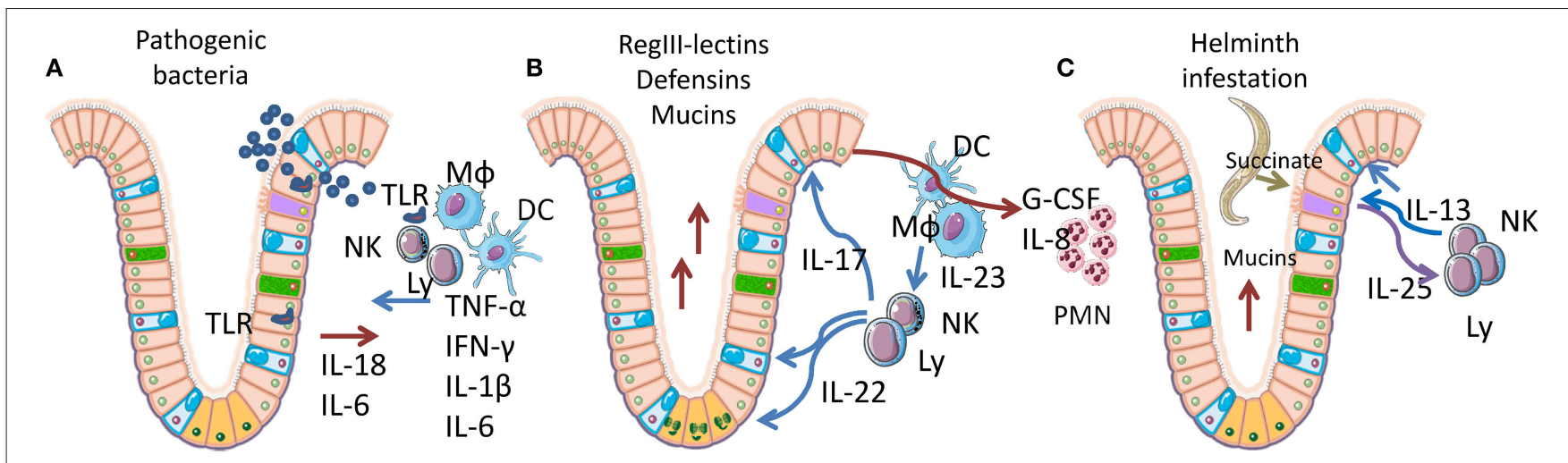

FIGURE 2 | Epithelial-immune cell cross-talk in gut mucosa. Simplified representation of the cytokine networks activated by the response to bacteria or parasites. Pink, enterocytes; yellow-orange, LGR5+ stem cells; cyan, goblet cells; purple, tuft cells; green, neuroendocrine cells; M $\phi$, macrophages; DC, dendritic cells; Ly, lymphocytes; NK, natural killer cells. (A) Acute inflammation caused by pathogenic bacteria is recognized through Toll-like receptors (TLR) and induces IL18 and IL6 release by IECs, followed by TNF $\alpha$, IL1 $\beta$, IFN $\gamma$, and IL6 release by lymphoid and myeloid cells. These cytokines trigger mucosal permeabilization and increase IEC proliferation and death. (B) Homeostatic inflammation, sustained by IL22 and IL17, secreted by lymphoid cells upon IL23 stimulation by myeloid cells. IL22 specifically targets IECs, restoring the epithelial barrier (tight junction formation), inducing the proliferation of LGR5 ${ }^{+}$stem cells in the crypt bottom. IL22 also induces hyperplasia in goblet cells, with increased mucins production. IL17 induces G-CSF and IL8 expression in IECs, fibroblasts and leucocytes causing neutrophils recruitment. (C) Parasite infection sensed by tuft cells, which are able to recognize succinate that is released by many helminths. Tuft cells react by expressing IL25, which induces IL13 release and activation of ILC2 cells. IL13 mediates proliferation of tuft cells (amplifying the response) and goblet cell activation, finally determining a Th2 response.

that is associated with increased levels of $\mathrm{TNF} \alpha$ and IFN $\gamma$, and exacerbates into a chronic colitis mediated by commensal bacteria (90-92).

In the gut, the specific subunit IL22R1 is almost exclusively expressed by IECs, making them a relevant target of IL22 produced by ILC, NK cells, $\mathrm{CD} 4^{+}, \mathrm{CD}^{+}$, and $\gamma \delta \mathrm{T}$ lymphocytes. IL23, IL6, and IL1 $\beta$ are the main inducers of IL22, while TGF $\beta$ suppresses IL22 expression in all $T$ cell subsets and induces IL17 expression. The main intestinal IL22-producing cells are NKp46 and ROR $\gamma \mathrm{t}$ positive (mouse), or NKp44 and RORC positive (human) (93). These do not express IL17 and lack typical NK cell effector functions (94). IL22 promotes the secretion of mucus-associated molecules, like MUC-1,-3, and-13 and other anti-microbial proteins, from goblet cells, reducing bacterial translocation across the epithelial barrier (95-100).

IL22 and IL17 frequently act in concert to limit bacterial invasion. The most common forms of IL17 are IL17A and IL17F, which share the same receptor but do not have completely overlapping activities. NKp46 ${ }^{+} \mathrm{ROR} \gamma \mathrm{t}^{+} \mathrm{NK}$ and $\mathrm{T} \gamma \delta$ innate immune cells are able to secrete IL17 and play an essential role before activation of a full Th17 response. The main source of IL17 is Th17 lymphocytes, which have differentiated from naïve $\mathrm{CD}^{+} \mathrm{T}$ cells by APCs secreting TGF $\beta$, IL6, and IL21 and are activated by IL23. The IL17 receptor is expressed by leucocytes, IECs, vascular endothelial cells and FBs, and increases G-CSF, IL6, and IL8 release favoring granulopoiesis and neutrophil recruitment (Table 2 and Figure 2B). IL17 also contributes to strengthen the epithelial barrier by inducing tight junction formation in IECs. While an excess of IL17 contributes to $\mathrm{CD}$, its presence is required to inhibit invasive bacteria $(101,102)$.

\section{HUMAN NK CELLS AND IMMUNE RESPONSE TO GUT INFECTIONS}

Most of what is known about the role of NK cells in response to gut infections comes from murine models (103-108). Murine NK cells appear to be relevant for Listeria monocytogenes, Salmonella, Citrobacter rodentium, and Yersinia enterocolitica infections (103-108). An efficient response to these infections mediated by NK cells is dependent on cytokines, such as IL15 and IFN $\gamma$. All molecular mechanisms involved in rodent gut immunity are very well reviewed elsewhere (108) and a specific analysis is beyond the scope of this review. It is conceivable that human NK cells in the gut can play a role in eliciting inflammation during bacterial infections that is independent of viral clearance and tumor control. Indeed, NK cells, like other innate cells, such as macrophages and neutrophils, can use different TLRs, mainly TLR2, TLR3, TLR4, and TLR9, to interact with bacteria-associated peptidoglycans, lipopolysaccharides, virus-derived dsRNA, and DNA with CpG motifs (also known as pathogen-associated molecular patterns, PAMPs) (109) to elicit an inflammatory response (Figure 2A). IL12 and IL18 produced by mucosa-associated macrophages are responsible for amplifying the immune response mediated by NK cells. In turn, IFN $\gamma$ released by NK cells can trigger activation of myeloid cells to augment phagocytosis, respiratory burst and killing of bacteria (Figure 2B). These effects can further amplify the activation of NK cells and IFN $\gamma$ toxicity, leading to systemic inflammation. Patients suffering from sepsis show dysfunction of several leukocyte subsets, including NK cells, that can cause a decreased host response against the primary bacteria and favor superinfections by other bacteria or latent viral reactivation, ultimately leading to fatal outcomes (110). 
TABLE 2 | Cytokines involved in gut homeostasis and diseases.

\begin{tabular}{|c|c|c|c|c|}
\hline Cytokine & Producer cells & Target cells & Physiology & Disease \\
\hline $\mathrm{IFN} \gamma$ & $\mathrm{NK}, \mathrm{TL}, \mathrm{ILC}$ & $\mathrm{M \phi}, \mathrm{BL}, \mathrm{TL}, \mathrm{IECs}, \mathrm{END}$ & $\begin{array}{l}\text { Class II antigen expression, immunity, } \\
\text { epithelial/endothelial permeabilization }\end{array}$ & $\mathrm{CD}, \mathrm{UC}$ \\
\hline IL6 & $\mathrm{M} \phi$, IECs, END, FBs & BL, TL, FBs, HEP & $\begin{array}{l}\text { Pyrogen, induces acute phase proteins, } \\
\text { induces B and T cells maturation and } \\
\text { platelet production }\end{array}$ & $\begin{array}{l}\text { Chronic inflammation and } \\
\text { autoimmunity, CRC }\end{array}$ \\
\hline IL12 & DCs, M $\phi$, PMN & $N K, T L, I L C, T \gamma \delta$ & Th1 responses, TNF $\alpha$ and IFN $\gamma$ secretion & IBD \\
\hline IL13 & NK, TL, ILC, EO & $\mathrm{BL}, \mathrm{M \phi}$, IECs, FBs & $\begin{array}{l}\text { Th2 responses against helminths, goblet } \\
\text { cells activation and proliferation }\end{array}$ & $\mathrm{CD}, \mathrm{UC}$, fibrosis \\
\hline IL22 & ILC, NK, T $\gamma \delta, T L$ & IECs & $\begin{array}{l}\text { Secretion of antibacterial peptides and } \\
\text { mucins, LGR5 }{ }^{+} \text {stem cells proliferation }\end{array}$ & $\mathrm{CD}, \mathrm{CRC}$ \\
\hline IL23 & DCs & ILC, NK, T $\gamma \delta, T L$ & IL22 and IL17 expression, Th17 responses & $\mathrm{CD}, \mathrm{CRC}$ \\
\hline IL25 & Tuft cells, TL, Mast cells & ILC2 & Th2 responses against helminths & \\
\hline TGF $\beta$ & DCs, IECs, FBs & LT, IECs, FBs & $\begin{array}{l}\text { Inhibits Th1 and Th2 responses, induces } \\
\text { Th17 and Tregs, IgA maturation, FB } \\
\text { proliferation, IEC inhibition }\end{array}$ & $\mathrm{CD}, \mathrm{UC}, \mathrm{CRC}$ \\
\hline TNF $\alpha$ & M $\phi, T L, N K, P M N, E O, I E C, E N D, F B s$ & $\mathrm{M} \phi, \mathrm{TL}, \mathrm{PMN}, \mathrm{IEC}, \mathrm{END}, \mathrm{FBs}$ & $\begin{array}{l}\text { Pyrogen, induces acute phase proteins, } \\
\text { pro-inflammatory, cytotoxic responses, } \\
\text { epithelial permeability and IEC apoptosis }\end{array}$ & $\mathrm{CD}$, autoimmunity \\
\hline
\end{tabular}

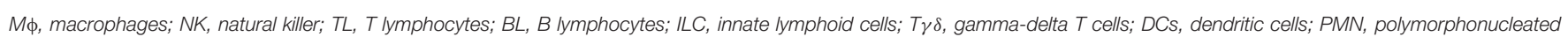

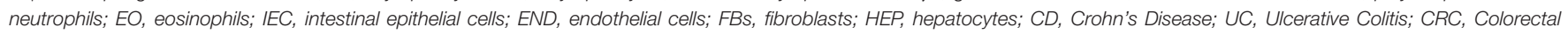
carcinoma; IBD, Inflammatory Bowel disease.

Focusing on NK cells in humans and NK cell-mediated anti-viral activity, interesting results analyzing the alteration of the mucosal distribution of NK cells during human immunodeficiency virus (HIV) infection have been reported (44). The frequency of NK cells is increased in HIV subjects with incomplete $\mathrm{CD}^{+} \mathrm{T}$ cell recovery in $\mathrm{PB}$ upon longterm anti-retroviral therapy. More importantly, spontaneous HIV controllers with protective KIR/HLA genotypes $(111,112)$ showed higher numbers of IEL NK cells than those in subjects with non-protective genotypes. This suggests that a peculiar NK cell subset displaying CD57 may be involved in control of HIV replication at the rectosigmoid mucosal site. Also, Human Herpesvirus 6 (HHV-6) can influence the NK cell-mediated response in the large bowel $(113,114)$. Indeed, HHV-6 shows a wide cell tropism in vivo and, as similar to other herpesviruses, causes a lifelong latent infection in humans and can be found in the large bowel. Notably, the HHV-6 products U51A and U83A suppress the surface expression of NKG2D and NKp30, two relevant activating receptors of NK cells (114). This suppression can impair the ability of NK cells to counteract HHV-6 reactivation and to recruit adaptive immune cells for elimination of the virus. In addition, some early viral proteins downregulate NKG2D ligands and transcription of B7-H6 mRNA, the reported cellular ligand of the activating receptor NKp30 (115) (Table 1). These findings suggest that the inefficient NK cell response can eventually lead to impaired clearance of HHV-6 and determine the establishment of a persistent infection (116).

\section{GUT MICROBIOTA AND IMMUNE RESPONSE: DIET AND PROBIOTICS}

Disorders in the development or composition of bacterial microbiota (known as dysbiosis) result in immunological dysregulation, leading to altered immune responses that may underlie disorders such as IBD, allergies, and cancer. In turn, the term "probiotic" is used to describe dietary microbes that confer a health benefit to the host (117). In animal models, diet-modified microbiomes can rapidly promote obesity or reduce incidence of diabetes, in association with decreased pro-inflammatory cytokines IL17 and IL23 in colon mucosa (118).

Diet, gut microbiota, and immune responses are probable explanations for the expanding incidence of inflammatory/immune diseases such as asthma, type 1 diabetes, and IBD in people living in developed countries (119). A low fiber intake adversely affects the intestinal microbiota and leads to decreased production of immunomodulatory products, in 
particular the short-chain fatty acids (SCFAs) acetate, propionate, and butyrate, all of which are critically important for mucosal immune homeostasis and intestinal epithelial integrity (120). For example, butyrate has an anti-inflammatory effect by inhibiting the recruitment and pro-inflammatory activity of neutrophils, macrophages, and effector $\mathrm{T}$ cells, and increasing the number of Tregs. IBD patients have reduced SCFA-producing bacteria and reduced butyrate concentration linked to a marked increase in the number of pro-inflammatory immune cells in the gut mucosa (121).

Intestinal APCs protect the body against infections, and having co-evolved with microbiota, maintain immune tolerance to the normal gut microbiota. For example, DCs of Peyer's patches in mice produce high levels of IL10, and gut macrophages, located in close proximity to the intestinal microbiota, develop a non-inflammatory phenotype termed "inflammation anergy" when encountering microbial stimuli in homeostatic conditions (122).

Probiotic bacteria are considered to be "generally recognized as safe (GRAS)" organisms by the Food and Drug Administration in the United States (123). It is supposed that probiotic bacterial cells and/or their soluble factors exert immunomodulatory effects by activating TLR on gut DCs and macrophages, driving APCs to produce cytokines required for antigen-specific Th1 polarization, such as IL12, or leading to immunological tolerance. Lactobacillus rhamnosus GG (LGG) can relieve intestinal inflammation in patients with atopic dermatitis and food allergy by decreasing TNF $\alpha$ production and promoting IL10 expression $(123,124)$. In addition, LGG has also been shown to induce intestinal secretion of IgA in atopic children (124). A synbiotic (synergistic combinations of probiotic and prebiotic) comprising Bifidobacterium longum has been demonstrated to reduce CD in a randomized double-blind placebo-controlled study with an evident decrease in TNF $\alpha$ expression (125).

Along this line, Lactobacillus plantarum ( $L p)$ can efficiently increase the expression of the natural cytotoxicity receptor (NCR) family and of IL22 in NK cells (126). Transfer of PB NK cells stimulated by $L p$ conferred protection against intestinal epithelial barrier damage induced by enterotoxigenic Escherichia coli (ETEC) in NCM460 cells in vitro. PB NK cells stimulated by $L p$ could partially offset the reduction in transepithelial electrical resistance (TEER) of NCM460 cell monolayers caused by ETEC. Furthermore, $L p$-stimulated, compared to $L p$-unstimulated, NK cells added to ETEC-infected NCM460 cells increased the expression of IL22R1, p-Stat3, and p-Tyk2 by NCM460 cells, which, together with ZO-1, claudin-1 and occludin, are known to play important roles in intestinal epithelial barrier function (127). Mechanistic experiments using polyclonal blocking antiIL22 antibody showed that $L p$-stimulated NK cells lost the ability to maintain TEER in NCM460 cells challenged with ETEC (127). These results suggest that $L p$ stimulation of NK cells could enhance IL22 production, which in turn provides defense against ETEC-induced damage to the intestinal epithelial barrier. Further studies demonstrated that treatment with different strains of $L p$ induces TRAIL on the cell surface of PBMCs. TRAIL production depended on IFN $\alpha$ and IFN $\gamma$ and facilitated NK cell activity exerted by PBMCs against cancer cells (128).
Aging leads to a decline in immune function that adversely affects gut microbiota. In a prospective double-blind, randomized crossover study in 40 healthy elderly subjects (aged 60-80 years) consumption of Lactobacillus rhamnosus GG combined with soluble corn fiber increased NK cell activity, decreased the pro-inflammatory cytokine IL6 and decreased total and LDL cholesterol (129). In another phase II randomized, doubleblinded, placebo controlled clinical trial, Lactobacillus salivarius treatment significantly increased the percentage of NK cells and monocytes, as well as the plasmatic levels of immunoglobulins and the regulatory cytokine IL10 (130).

The GI tract contains the largest endocrine organ in the body. Due to the strategic location of enteric endocrine cells in gut mucosa, interactions with the immune systems are very likely to play an important role in immune modulation (131). At least 14 different populations of enteric endocrine cells release biologically active compounds $(132,133)$. Although some data on the influence of these substances on Th1/Th2 responses in the gut are available $(132,133)$, to our knowledge information on NK cell recruitment and function is lacking.

\section{INFLAMMATORY BOWEL DISEASE (IBD) AND NK CELLS}

Overpowering cytokine production and chronic inflammation are typical of IBD, mainly represented by $\mathrm{CD}$ and ulcerative colitis (UC) $(2,134,135)$. While the cause of IBD is still unknown, it is conceivable that associations between the altered immune response against intestinal flora and the genetic background of susceptible individuals could be responsible. Many studies have reported the linkage between the IBD3 region in the human leukocyte antigen (HLA) complex and CD or UC (136). Likewise, major histocompatibility complex (MHC) class I chain-related molecules (MIC) alleles and MICA polymorphisms have been associated with IBD [141, 142].

There is evidence that supports a major role for adaptive immunity in the pathogenesis of IBD, involving Th1 and Th2 cells, together with other subsets of $\mathrm{T}$ cells, namely Th17 and Tregs $(134,135)$. In particular, while it has long been thought that $\mathrm{CD}$ is due to an abnormal Th1 response with increased secretion of the pro-inflammatory cytokines IFN $\gamma$ TNF $\alpha$ and IL1 $\beta$ (Figure 3A), UC has been associated with a non-conventional Th2 response that involves IL5, IL6, and IL13 (Figure 3B) $(134,135)$. Besides classical Th1 and Th2 responses, Th17 cells, which are a subset of T lymphocytes that expand in the presence of IL23, can also contribute to IBD pathogenesis through IL17 production (137). More recently it has been shown that the innate arm of immune response is relevant to the favoring of gut inflammation in IBD patients (137). While altered epithelial barrier function has been described in patients with CD and UC, it remains unclear whether these lesions represent the cause or the effect of chronic inflammation with intensified production of cytokines. Among the highly produced cytokines, IL23, besides amplifying the IL17 circuit, can also act on innate immune cells or unconventional T lymphocytes, such as $\gamma \delta \mathrm{T}$ lymphocytes which are good producers of IL17, or NK cells (138). 
In this regard, the presence of killer (K) cells in mesenteric LN was described in CD patients long ago (139). The involvement of NK cells in IBD pathogenesis has been supported by a recent study on polymorphisms of killer immunoglobulin-like receptors (KIR) genes (140). KIR are NK cell surface receptors, which bind to the class I MHC and have inhibitory or activating effects on NK cells (Table 1). A meta-analysis of $432 \mathrm{UC}$ and $1677 \mathrm{CD}$ patients showed positive associations between 2DL5/2DS1 (members of KIR genes) and UC risk, and a negative association between 2DS3 and CD risk (140).

\section{Crohn Disease (CD)}

Aberrant innate immune responses, such as huge antimicrobial peptide production and enhanced innate microbial sensing and autophagy, are associated with CD pathogenesis (134). How NK cells contribute to this uncontrolled immune amplification is still unclear, nevertheless several groups have recently identified a unique subset of mucosal $\mathrm{NK}$ cells that contributes to local immunity. These mucosal NK cells in the human gut are distinct from conventional NK cells and are characterized by expression of the transcription factor retinoic acid-related orphan receptor C (RORC), CD127 (IL7R $\alpha)$, and NKp44 or NKp46 (Table 1). Moreover, NKp44 ${ }^{+}$NK cells produce IL22 (141), however whether they participate in pathologic or protective processes of chronic inflammation in vivo remains controversial. In humans, $\mathrm{CD}{ }^{+} \mathrm{CD} 127^{+} \mathrm{NK}$ cells are generated from LTi cells and produce little IFN $\gamma$, whereas $\mathrm{CD} 56^{+} \mathrm{CD} 127^{-} \mathrm{NK}$ cells produce a large amount of this cytokine. NKp44 and NKp46 are expressed differentially on NK cells in the CD intestine, NKp46 ${ }^{+} \mathrm{NK}$ cells predominate in intestinal mucosa of patients with $\mathrm{CD}$ compared with patients with UC and with controls. Upon interaction with intestinal inflammatory macrophages, $\mathrm{NKp} 46^{+} \mathrm{NK}$ cells from patients with CD are activated via IL23 and produce IFN $\gamma$ (93).

Of note, genetic alterations in regulatory NK cell receptors have been reported. Indeed, KIR polymorphism is implicated in susceptibility to CD (140), with a significant association of the KIR2DL3/HLA-C1 genotype and CD (142), although the cellular mechanism of this genetic contribution is poorly defined. It has been described that the "licensing" of NK cells, determined by the presence of KIR2DL3 and homozygous HLA-C1 in the host genome, results in cytokine reprogramming that permits promotion of $\mathrm{CD} 4{ }^{+} \mathrm{T}$ cell activation and Th17 differentiation ex vivo. Licensed NK cells are more polarized to pro-inflammatory cytokine production than unlicensed NK cells. These cytokines, including IFN $\gamma, \mathrm{TNF} \alpha$, and IL6 (Table 2), augment CD4 ${ }^{+} \mathrm{T}$ cell proliferation and IL17A/IL22 production. Interestingly, antibody blocking of these cytokines could reduce their effect (143), presenting a potential therapeutic target for $\mathrm{CD}$ and other IBD (144). However, due to the complexity of the cytokine network involved and the fact that Th17 cells may also have protective functions, neutralization of IL17A failed to induce any improvement in $\mathrm{CD}$, at variance with other autoimmune disorders $(145,146)$.

An exploratory clinical trial to investigate the safety and efficacy of the humanized anti-IL6R mAb tocilizumab (also known as MRA) in patients with $\mathrm{CD}$, showed promising results, with $20 \%$ of the patients entering remission and acute-phase responses normalized by a single MRA infusion (147). However, the gold standard IBD treatment, including $\mathrm{CD}$, for many years has been based on the use of humanized or human anti-TNF $\alpha$ antibodies, despite many adverse effects-including the risk of tuberculosis (148).

Since CD pathogenesis has been linked with the IL12/23 pathway $(138,143,149)$, a recent novel approach to interrupt this pathway has been proposed using ustekinumab, a therapeutic monoclonal antibody that blocks the p40 subunit of both IL12 and IL23 and prevents interactions with their receptors on T, NK, and APCs, has established efficacy in psoriasis (150).

Another important mechanism in the pathogenesis of $\mathrm{CD}$ is the expression of stress-related molecules belonging to the MIC family $(136,151)$. These molecules are recognized by NKG2D receptors (Table 1) expressed on T and NK cells and induce activation of these cytolytic cell types, thus contributing to mucosal cell damage $(152,153)$. A recent phase II clinical trial showed that an antibody against NKG2D induced clinical remission of CD in some patients, suggesting NKG2D and its ligands are attractive new targets for IBD therapies $(152,154)$.

\section{Ulcerative Colitis (UC)}

$\mathrm{UC}$ is characterized by contiguous inflammation of colonic LP wherein damage is triggered by an over-response to bacterial antigens, enhancement of DC and macrophage stimulation via TLRs $(155,156)$. In UC, the T-cell response to antigens is not Th1 dominant, as in the case of CD, but rather is either Th2 (IL4, IL13) dominant, or is mediated by specialized cells such as natural killer-like T (NKT) cells producing IL13 (Figure 3B). LP-NKT cells from UC patients produce significantly greater amounts of IL13. Thus, UC pathogenesis is considered to be an atypical Th2 response mediated by a distinct subset of NKT cells that produce IL13 and damage epithelial cells $(156,157)$. Along this line, decreasing IL13 production following treatment with IFN $\beta 1 \mathrm{a}$ is associated with clinical improvement of UC symptoms (158). Other inflammatory cytokines (TNF $\alpha$, IL1, IL6, IL9) play significant roles in worsening, while anti-inflammatory cytokines (TGF $\beta$, IL10) delay disease progression (156).

In this context, the actual pathogenetic role of $\mathrm{NK}$ cell is still undefined. KIR polymorphism and positive associations between 2DL5/2DS1 KIR and UC risk has been reported (140, 159). In active UC, peripheral NK cells were decreased significantly compared to inactive UC. After anti-TNF treatment, peripheral NK cells in responsive IBD patients were significantly higher than in non-responsive UC (160). Intestinal LP NKG2D ${ }^{+} \mathrm{NK}$ cells have been investigated in UC, since it is thought that they play a role in regulating Th1/Th2 balance (Figure 3B). Severe UC patients have higher expression of mucosal NKG2D and its ligand MICA, and a lower number of $\mathrm{LP} \mathrm{NKG} \mathrm{D}^{+} \mathrm{NK}$ cells than mild to moderate UC. Furthermore, in bioinformatics analyses, mucosal Th1 cytokines, mainly $\mathrm{TNF} \alpha$, emerged as crucial to $\mathrm{CD}$, but not UC, since anti-TNF $\alpha$ treatment proved less effective than in CD. This would suggest that $\mathrm{NKG}_{2} \mathrm{D}^{+} \mathrm{NK}$ cells play a regulatory role in UC by secreting Th1 cytokines that modulate the Th2-predominant Th1/Th2 imbalance (160). Although the precise role of NKG2D is less clear in UC pathogenesis than in $\mathrm{CD}$, this molecule should be considered as a possible therapeutic 

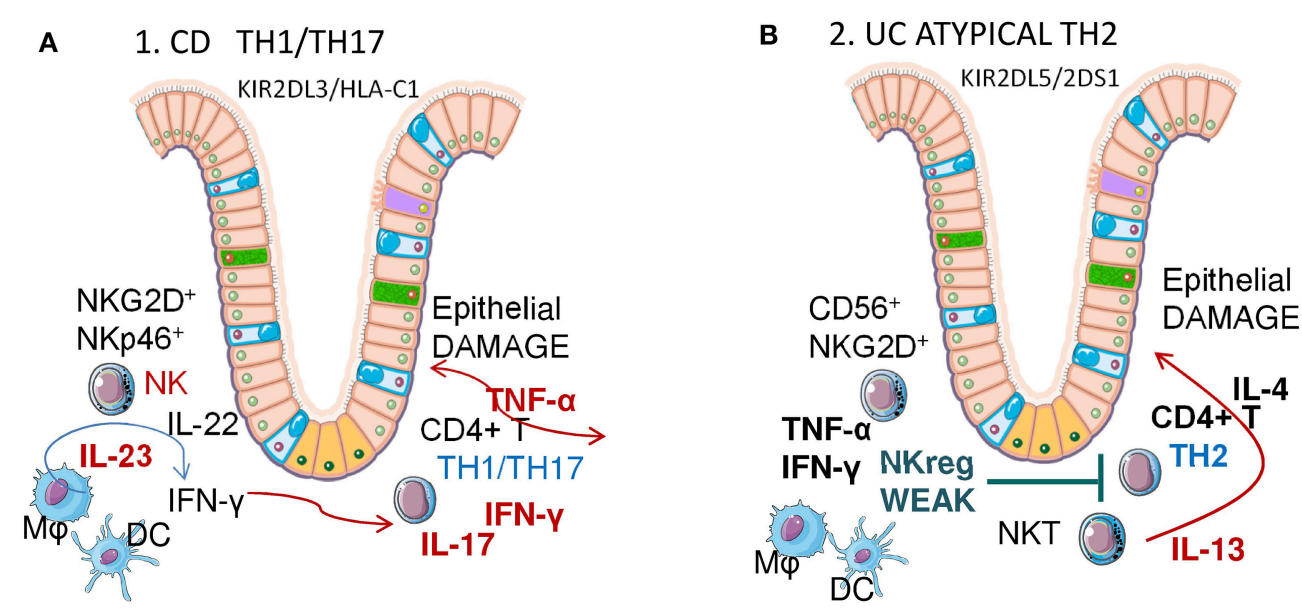

FIGURE 3 | Crohn Disease (CD) and Ulcerative colitis (UC) pathogenesis: possible role of NK cells. Different Th1/Th2 responses in CD and UC. M $\phi$, macrophages; DC, dendritic cells; NK, natural killer cells; NKT, natural killer-like T cells. (A) Crohn's Disease is mainly a Th1/Th17 IBD, linked to a KIR2DL3/HLA-C1 genotype in NK cells. Mucosal NK cells are RORC, CD127 (IL7R $\alpha$ ), NKG2D and NKp46 positive, produce IL22 and IFN $\gamma$ when activated via IL23 and contribute to the expansion of $\mathrm{CD}^{+}$Th1/Th17 lymphocytes that, in turn, secrete both IFN $\gamma$ and TNF $\alpha$, in addition to IL17. (B) Ulcerative Colitis is mainly an atypical Th2 IBD, linked to a KIR2DL5/2DS1 genotype in NK cells. Atypical NKT produce IL13, which induces epithelial damage. In turn, NK cells are unable to induce an efficient TNF $\alpha$ IFN $\gamma$ response to reduce the Th1/Th2 imbalance, contrasting excessive IL13 secretion.

target as well (153). Finally, NK cells can be targeted in CD by 6-mercaptopurine, a drug also used in UC treatment that causes NK cell apoptosis and depletion, which possibly limits the inflammatory response (161).

\section{NK CELLS IN COLORECTAL CANCER (CRC)}

$\mathrm{CRC}$ has been recently subdivided into four consensus molecular subtypes (CMS) on the basis of genetic and microenvironmental signatures. Three of these classes recall the well-known definitions of microsatellite instable (CMS1), sporadic (CMS2) and stromal rich (CMS4) CRC, while the class of metabolic CRC (CMS3) was recently introduced. In CMS2 and 3, comprising about $50 \%$ of all CRC, immune and stromal infiltration are limited. CMS1 (14\%), due to microsatellite instability (MSI), has a high DNA mutation rate, causing the production of altered antigens that trigger the immune response. Accordingly, CMS1 shows a strong infiltration of innate and adaptive immune cells. It is not by chance that only MSI-high CRC showed a clinical response to anti-PD-1 and anti-PD-L1 immune checkpoint inhibitors therapy $(162,163)$. CMS4 $(23 \%)$ defines a particular group of CRC showing a strong infiltration of stromal cells, such as FBs, an intermediate infiltration of immune cells and a minority of tumor cells. Despite the low prevalence of tumor cells, this CRC subtype has the worst prognosis. CMS4 is characterized by high TGF $\beta$ expression, determining an immunosuppressive microenvironment that is enriched in regulatory cells (164). In this regard, CRC-associated FBs cocultured in vitro with NK cells can downregulate the expression of NKG2D and the NKG2D-mediated recognition of tumor target cells by NK cells (165).
CRC frequently shows diminished MHC class I expression, that would increase tumor susceptibility to attack by NK cells. In CRC with partial or total HLA class I loss, effector IELs are $\mathrm{CD} 8^{+} \mathrm{CTL}$, while $\mathrm{NK}\left(\mathrm{CD}^{+} 6^{+}\right)$cells are only observed scattered in the stroma. On the contrary, in normal mucosa, $\mathrm{NKp} 6^{+} \mathrm{CD}^{-} \mathrm{NK}$ cells can also show intraepithelial localization and typically coexpress CD57 $(46,166)$ (Figure 4). To our knowledge, immunohistochemical studies on the NK cell population of CRC systematically used anti-NKp46 antibodies, thus no information about the NKp44 $4^{+}$population is available. The quantification of $\mathrm{NKp} 44^{+}$cells in the tumor infiltrate of CRC patients could be of great interest, as it has been shown that CRC-initiating cells preferentially express ligands for NKp30 and NKp44 $(93,167)$. CRC shows a reduced number of infiltrating NK (NKp46 ${ }^{+}$) cells compared to normal mucosa, also when $\mathrm{CD}^{+} \mathrm{T}$ cell numbers are elevated, suggesting that CRC is able to limit NK cell infiltration. This limitation of NK cell recruitment is not mediated by the absence of homing chemokines as CXCL9, CXCL10, CCL3, CCL4 (active on CD56 $6^{\text {bright }}$ NK cells) and CXCL8, CXCL1, CXCL5, CXCL12 (active on CD56 ${ }^{\text {dull }}$ NK cells) show higher concentrations in the tumor than in the unaffected mucosa. Despite the reduced number in $\mathrm{CRC}$, the $\mathrm{NKp} 46^{+} \mathrm{CD}^{-} \mathrm{NK}$ population is enriched in $\mathrm{CD}_{16}{ }^{+} \mathrm{CD} 56^{+}$cells compared to normal mucosa, suggesting that ADCC could be elicited by humanized $A b$ targeting tumor cells $(76,165)$. The contemporary infiltration of $\mathrm{CD}^{+} \mathrm{T}$ and $\mathrm{NK}$ cells in $\mathrm{CRC}$ is apparently linked to a better prognosis compared to the infiltration of $\mathrm{CD}^{+} \mathrm{T}$ cells only. This effect could be due to direct involvement of NK effectors, or represent a less immunosuppressive microenvironment of the tumor (168). A proof of principle for the efficacy of NK cell reactions against CRC comes from a recent case-report describing a complete and sustained response 


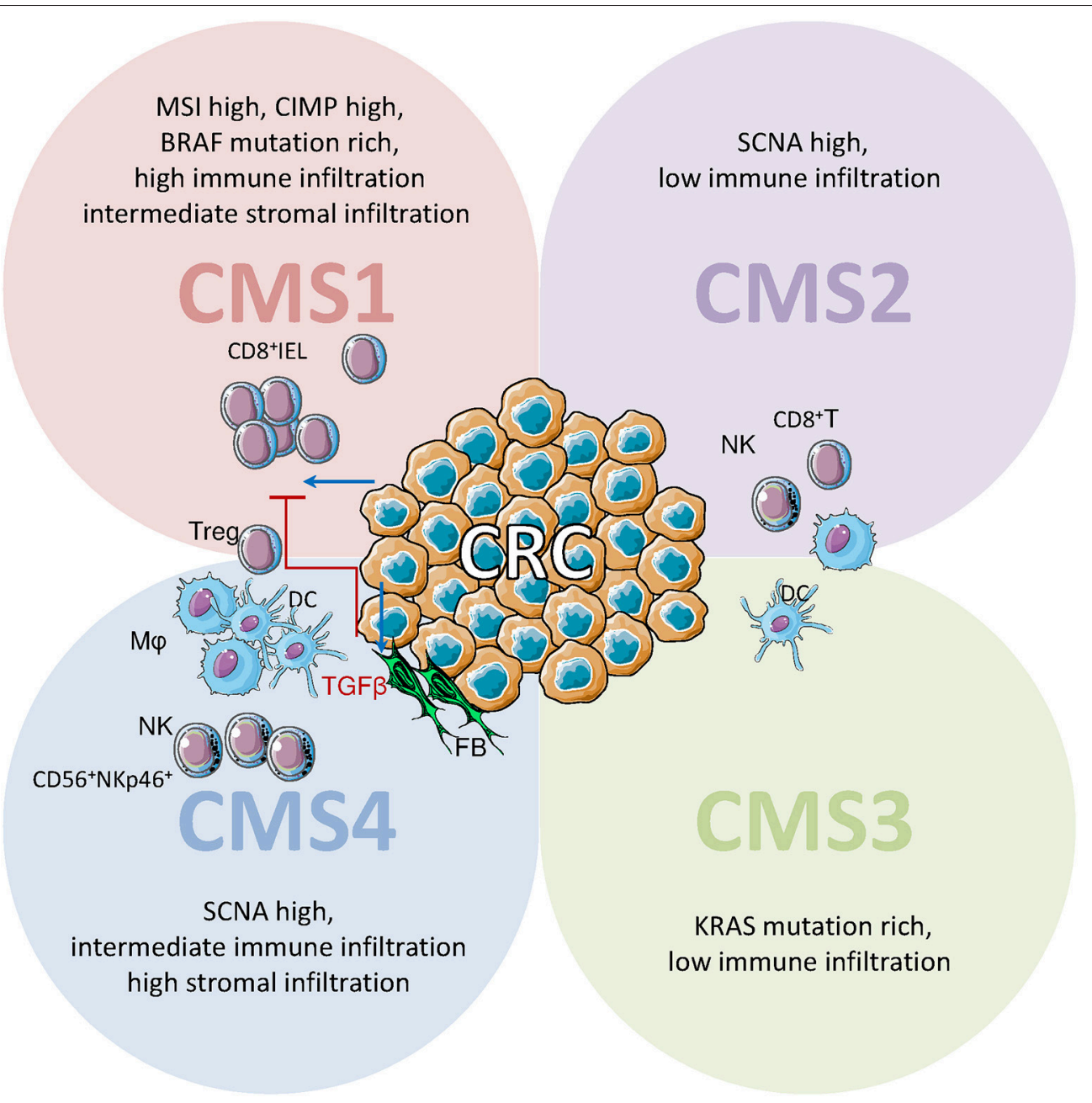

FIGURE 4 | Immune cell infiltrate in CRC: possible role of NK cells. Schematic representation of immune cell infiltrate in CRC defined on the basis of gene expression profiles in consensus molecular subtypes (CMS). IELs: intraepithelial lymphocytes; M $\phi$, macrophages; DCs, dendritic cells; NK, natural killer cells; FBs, fibroblasts. IELs are CD8 ${ }^{+}$cytolytic T lymphocytes (CTL), while CD56 ${ }^{+} \mathrm{NKp}_{6}{ }^{+}$NK cells are scattered in the stroma. CMS1 (14\% of CRC, upper left) are characterized by high somatic copy number alteration (SCNA), high CpG island methylator phenotype CIMP), and a strong microsatellite instability (MSI); this high DNA mutation rate leads to altered antigens that trigger immune responses and causes a strong infiltration of innate and adaptive immune cells. In CMS2 and CMS3 (50\% of CRC, upper right and lower right) immune and stromal infiltration are limited. CMS4 (23\% of CRC, lower left) shows a strong infiltration of stromal cells (FBs) and intermediate infiltration of immune cells. In CMS4 high TGF $\beta$ expression determines an immunosuppressive microenvironment enriched in regulatory T cells.

mediated by NK cell activation, in a metastatic CRC patient (169). Indeed PVR (CD155), Nectin-2 (CD112), and MICA/B, the ligands for the activating $\mathrm{NK}$ receptors DNAM1 and NKG2D, are expressed in CRC, suggesting a possible target for NK effectors. Though CRC infiltrating NK cells show a partially reduced expression of DNAM1 and NKG2D, increased soluble (s)CD155, and sMICA/B have been detected in patient serum (170).

A TMA study on 462 primary colorectal tumors evaluated MIC, ULBP, RAET (NKG2D ligands) and the NK cell infiltration. The higher expression of all ligands was found in stage I (UICC-TNM) tumors, becoming less frequent in advanced stages. MIC levels correlated to NK infiltration. The contemporaneous high expression of MIC and RAET1G was linked to improved patient survival of 77 months over CRC expressing one ligand or low levels of both (171). According to these observations, the future clinical application of NKbased immunotherapies against CRC apparently depends on the identification and neutralization of the tumor-derived mediators that limit NK cell infiltration. As these mediators do not apparently influence $\mathrm{CD}^{+} \mathrm{T}$ lymphocyte recruitment, they should probably be looked for among signaling molecules specific for NK cells. Among them, KIR and CD16 have been implicated in defining CRC genetic risk and clinical stage, although the matter is still under debate (172-174). Indeed, the allele frequency of KIR2DL2 and KIR2DS2, in the absence of their cognate HLA-C1 ligands, were significantly associated with reduced genetic risk of CRC. Conversely, CD16-48H polymorphism was associated with increased genetic risk of CRC (172). In 1990 Adachi et al. reported a higher 
number of $\mathrm{CD}^{+} 7^{+} \mathrm{NK}$ cells in draining CRC LN than in primary or metastatic lesions and suggested that these cells can limit tumor spreading (175). Indeed, acquisition of CD57 represents a shift toward a higher cytotoxic capacity, greater responsiveness to signaling via CD16 and NCR and decreased responsiveness to cytokines. This would be consistent with enhanced tumor surveillance/cytotoxicity of the mature, $\mathrm{CD} 57^{+}$ NK cell subset (46).

As discussed above, mucosal epithelium is a source and a target of several cytokines (Table 2) (176). In particular, IL18 is a typical cytokine produced by the normal mucosa and is decreased in CRC: its downregulation frequently correlates with a lack of IFN $\gamma$ and FAS ligand, and formation of metastases. IL18 primes NK cells in vivo to produce IFN $\gamma$ upon stimulation with IL12 and increases IFN $\gamma$ neosynthesis in NK cells activated through CD16. In mouse models, IL18 limits the differentiation of Th17 cells and sustains epithelial regeneration upon inflammatory damage (177179). IL22, produced by ILC, NK and T lymphocytes, binds only to IECs, representing a more defined target for CRC therapies. Indeed, IL22 has been associated with CRC growth, tumor cells protection from cytotoxic and apoptotic effects of chemotherapy and FOLFOX resistance in CRC patients (180-182).

IL12 is formed by IL12p35 and IL12p40 subunits. IL12p40 can also form a homodimer, antagonizing IL12 activity, or bind IL23p19 to form IL23; hence the overall effect of the single cytokine can be elusive. NK and $\gamma \delta \mathrm{T}$ cells express high levels of IL12 receptor. IL12 plays a central role in Th1 responses, triggering the activation of $\mathrm{NK}$ and $\mathrm{CD} 8^{+}$ $\mathrm{T}$ cells and inducing IFN $\gamma$ production. In CRC patients, a low production of IL12 in DCs was associated with a poor prognosis (183-185). Despite the shared subunit with IL12p40, IL23 activates local inflammatory responses not involving Th1 effectors. IL23 is secreted by DCs, macrophages, and neutrophils during gut inflammation (Table 2). The main intestinal targets of IL23 are Th17, ILCs, and Tregs, inducing the production of IL22 and IL17. High IL23 levels, coupled with low SOCS3 expression in primary $\mathrm{CRC}$, were predictive of increased risk of metastasis (186).

Despite the lack of data on NK cells and IL17, this cytokine is of interest as it shows a controversial influence on CRC. A genetic clustering of 125 CRC showed reduced survival of patients with a high Th17 signature. However, a tissue microarray evaluation of $\mathrm{IL}_{1} 7^{+}$cells in 1148 CRC samples did not confirm this observation, as IL17 positive staining was correlated with neutrophils and $\mathrm{CD} 8^{+}$ cytotoxic lymphocytes infiltration, and intraepithelial Th17 lymphocytes were linked to a favorable prognosis. Thus, the overall effect of IL17 is apparently linked to the localization of IL17-producing cells. A further complication in the definition of the pro-tumor properties of IL17 comes from the IL17A polymorphism rs2275913 (G197A), with the AG and AA genotypes strongly associated to an increased CRC incidence (187-191).

\section{NK/IMMUNE CELL-EXOSOMES CONNECTIONS: ROLE OF SIGNALS ORIGINATING IN GUT CELLS OR MICROBIOTA}

The importance of extracellular nanovescicles (EVs), ranging from 50 to $1,000 \mathrm{~nm}$ in size, exosomes in particular (size 100$200 \mathrm{~nm}$ ), as biological vehicles able to affect distant organs is well established. For example, salivary exosomes from patients with IBD, a condition predisposing toward UC and CRC, carry larger amounts of proteasome subunit alpha type 7 (PSMA7) than those in healthy subjects. High-throughput sequencing revealed $\sim 850$ proteins in EVs secreted by intestinal cells and present in ascites of patients with CRC, showing that intestinal EVs may be transferred between organs and, in turn, modify the composition of EVs released by the target tissue (192). For a thorough examination of the state of the art of characterization and use of exosomal vesicles, we refer to recent comprehensive reviews $(193,194)$.

NK and organ cells apparently communicate in forward and backwards signaling loops where cell- and NK-derived exosomes exert reciprocal control in the circuit. The impact of intestinal physiology, depending also on the balance of the gut microbiota, on the immune system at the whole-body level has recently emerged as a crucial topic in cancer research and in research of related conditions (chronic inflammation, angiogenesis and metabolic syndrome, to cite a few). Responses to immunotherapy and metastatic dissemination seem to depend, at least in part, on the gut microflora-host interplay. In a remarkable in vivo preclinical study, the exodus of gut-primed immune cells in mice engineered with the fluorescent Kaede protein provided evidence of an intense two-way trafficking from defined colon tracts to lymphoid organs. Also specific LN at sites distant from the intestine, besides mesenteric LN, were the destination of Tregs, Th17, and other innate and adaptive immune cells involved in chronic intestinal and systemic inflammation (195). This work highlights the powerful potential of gut homeostasis and dysbiosis on control of health; however, a possible role for gut or immune cell EVs in these conditioning pathways was not examined. The influence of gut exosomes on the immune system is currently being intensely investigated, with efforts primarily focused on intestinal DC EVs and adaptive immunity cross-talk (196). Several experimental models have advanced knowledge of the effects of intestinal mucosa EVs on innate immune cells (mostly neutrophils, monocytes and macrophages), and vice versa, in inflammatory diseases of the GI tract (197).

Indeed, different preclinical studies have shown that tumor EVs promote tumor cell organotropism, favoring a premetastatic niche in the host microenvironment. A role for tumor EVs in metastatic progression has been reported for CRC, gastric (GC), and pancreatic ductal adenocarcinoma (PDAC) invading the liver microenvironment. Stromal cells seem to be the privileged targets of tumor exosomes in the metastatic organ, establishing a pro-inflammatory and immunosuppressive state (198). 


\section{Effects of Cellular Exosomes on NK Cell Function}

The data reported focus primarily on NK cell activation induced by exosomes released by DCs, stressed cells, or tumor cells. EVs, particularly tumor EVs, are endowed with anti- or pro-tumor potential, and a dual immunostimulatory or immunosuppressive role. NK cell activation is only one of the multiple and contrasting functions of cellular EVs, and the final outcome at the level of the organ and the whole body, as well as on the disease state, comes from the prevailing effect.

DC-derived exosomes (Dexs) can boost NK effector functions through the binding of Dexs carrying TNF $\alpha$ to TNFR on NK cells, which stimulates the release of IFN $\gamma$ and the cytotoxic response (199). Dexs have been shown to trigger NKG2D-dependent NK cell expansion and activation in lymphoid organs in mice (200). Moreover, Dexs express the nuclear/membrane protein BAG6, a ligand for the activating NCR NKp30 (Table 1). BAG6expressing Dexs induce cytokine release by NK cells and their effector program (201). Dexs have the ability to directly kill $\mathrm{T}$ and NK cells, via Fas-L, TRAIL and other death receptors (199). As we will discuss later, Dexs can also kill tumor cells by similar mechanisms, opening new ways for anticancer therapies to target cancers.

A prominent immunosuppressive function for tumor EVs is apparently mediated by TGF $\beta 1$ and NKG2D ligands. It is wellestablished that intestinal epithelial cell EVs carrying abundant $\alpha v \beta 6$ integrins can prime DCs and Tregs to produce active TGF $\beta$ from the latent form, thus acquiring a tolerogenic phenotype (202). Nevertheless, the stress-induced heat shock proteins (Hsps) are known to confer tumor immunogenicity and induce NK antitumor responses (203), and EVs expressing high levels of Hsp60 have been found in CRC. Exosomes carrying abundant Hsps have been shown to effectively limit liver metastasis in CRC and gastric cancer (204).

Pharmacological stress triggered by anticancer drugs, such as carboplatin and irinotecan, can also induce exosomal Hsps in hepatic carcinoma that can trigger NK antitumor activation. Membrane-bound Hsp70 is a tumor structure that enhances the cytotoxic attack by NK cells, improving their effectiveness. CRC EVs expressing Hsp70 can induce activating NK cell receptors, such as CD69, NKG2D, NKp44, and down-regulate the inhibitory NK receptor CD94, enhancing granzyme Bmediated NK cytotoxicity $(204,205)$. Tumor exosomes have been found to frequently exert immunostimulatory effects through the expression of BAG6/BAT3, a ligand for NK cell NKp30 activating receptor, normally expressed in DCs, as mentioned above.

The data available on the interactions between tissue or NK EVs in the gut are scarce. GI epithelial cells secrete EVs (206) and EV recipient cells include intestinal macrophages and DCs in the LP, which acquire information from the epithelial cells themselves or from luminal antigens provided by goblet cells. EVs secreted by intestinal mucosa, expressing intestinal epithelial-specific markers (A33, villin-1) and $\mathrm{PGE}_{2}$, can deliver their content to APCs or NKT cells in the liver. This initiates an immunosuppressive program in the organ and an anergic-like state in NKT cells that can inhibit the anti-tumor response. The immunosuppressive effects of intestinal EVs, however, could also be exploited to limit liver autoimmune attack (207).

\section{Effects of DCs and NK Exosomes on Neighboring Cells}

Dexs, which have been thoroughly characterized, retain and expose proteins, ranging from presentation molecules (class I and class II MHC peptide complexes and CD1), costimulatory molecules (CD86, CD40), adhesion (ICAMs), and docking molecules (integrins), on the outer membrane. Clinical grade Dexs are of great value as more effective inducers of tumor-associated antigen (TAA)-specific $\mathrm{T}$ cell responses than DCs in novel immunotherapy strategies, and are currently being evaluated in clinical trials for vesicle-based cancer treatment (208).

Exosomes derived from NK cells were described in the context of immune surveillance against infectious agents and tumor cells by Lugini et al. (209, 210). Typical NK cells $\left(\mathrm{CD} 56^{+} \mathrm{CD}_{16}{ }^{+} \mathrm{CD}^{-}\right)$constitutively release exosomes in resting and activated states. NK vesicles can express the basal NK cell markers CD56, NKG2D, and, to a lesser extent, the NCR NKp46, NKp44 and NKp30, and the cytotoxic machinery of perforins and FASL to kill cancer cells. FASL, however, was undetectable in circulating serum exosomes (209).

Jong et al. recently showed that EVs released by activated NK cells induce caspase-3,-7 and-9, exerting a cytotoxic against a panel of different tumor cell lines (211). Besides perforin, these vesicles also contain granulysin, granzymes A and B. In this scale-up isolation procedure, activation and expansion of NK cells was obtained by incubation of PBMCs with artificial APCs, K562-mbIL21, expressing a membrane variant of IL21. NK cell expansion offers opportunities for preclinical studies and possibly for clinical applications in the future. Interestingly, an observational clinical trial at the Ottawa Hospital is presently recruiting healthy donors and $\mathrm{CRC}$ patients after surgery to measure NK cell activity by the classical $\mathrm{Cr}^{51}$ cytotoxicity assay. The scope of the study is to investigate the activation state of $\mathrm{NK}$ cells, in order to boost clearance of tumor metastasis by NK cells (212).

The potential theranostic uses of EVs, regardless of the cell from which they are secreted, are far from being fully exploited. The term "exosomes," however, has been reported in 99 clinical studies, covering 47 observational studies aimed at defining disease-specific molecular signatures and intercellular signaling of exosomal vesicles. Further studies on exosomes are needed to develop their possible use as potential diagnostic markers or therapeutic tools for drug delivery. As an example, the exosomal form of KIR might be a valuable indicator of gut disease stage and/or progression.

\section{FUTURE PERSPECTIVE TO STUDY NK CELLS IN HUMAN GUT}

The evidence outlined herein underscores the intrinsic difficulty in studying either the physiological or pathogenic role of NK cells 
in the human gut. Indeed, the complexity of the gut includes the cellular composition, the diet, and microbiota, the repertoire of hormones and cyto-chemokines, besides individual genetic background. On the other hand, NK cells and ILC are really rare and their precise identification is not easy. Nevertheless, the generation of organoids from colonic specimens and artificial scaffolds of the intestinal mucosa (213-215) suggest the possibility of studying the interactions of the NK-gut microenvironment in a more controlled experimental system. This approach might better define the relative contribution and relevance of NK cells and innate lymphoid cells in gut health and disease.

\section{AUTHOR CONTRIBUTIONS}

Although all the authors are responsible for and edited the whole content of this paper, some parts of the paper have been cured by a specific author. Briefly, AP wrote the introduction, NK cell features, mechanisms of localization of NK cells, some points on

\section{REFERENCES}

1. Carroll M. Innate immunity in the etiopathology of autoimmunity. Nat Immunol. (2001) 2:1089-90. doi: 10.1038/ni1201-1089

2. Geremia A, Arancibia-Cárcamo CV. Innate lymphoid cells in intestinal inflammation. Front Immunol. (2017) 8:1296. doi: 10.3389/fimmu.2017.01296

3. Fiocchi C, Tubbs RR, Youngman KR. Human intestinal mucosal mononuclear cells exhibit lymphokine-activated killer cell activity. Gastroenterology. (1985) 88:625-37.

4. Nalle SC, Turner JR. Intestinal barrier loss as a critical pathogenic link between inflammatory bowel disease and graft-versus-host disease. Mucosal Immunol. (2015) 8:720-30. doi: 10.1038/mi.2015.40

5. Bernink JH, Peters CP, Munneke M, te Velde AA, Meijer SL, Weijer K, et al. Human type 1 innate lymphoid cells accumulate in inflamed mucosal tissues. Nat Immunol. (2013) 14:221-9. doi: 10.1038/ni.2534

6. Bernink JH, Krabbendam L, Germar K, de Jong E, Gronke K, Kofoed-Nielsen M, et al. Interleukin-12 and-23 Control Plasticity of CD127(+) Group 1 and Group 3 Innate Lymphoid Cells in the Intestinal Lamina Propria. Immunity. (2015) 43:146-60. doi: 10.1016/j.immuni.2015.06.019

7. Purchiaroni F, Tortora A, Gabrielli M, Bertucci F, Gigante G, Ianiro G, et al. The role of the intestinal microbiota and the immune system. Eur Rev Med Pharmacol Sci. (2013) 17:323-33.

8. Jiménez-Dalmaroni MJ, Gerswhin ME, Adamopoulos IE. The critical role of toll-like receptors-From microbial recognition to autoimmunity: a comprehensive review. Autoimmun Rev. (2016) 15:1-8. doi: 10.1016/j.autrev.2015.08.009

9. Ochoa MC, Minute L, Rodriguez I, Garasa S, Perez-Ruiz E, Inogés $\mathrm{S}$, et al. Antibody-dependent cell cytotoxicity: immunotherapy strategies enhancing effector NK cells. Immunol Cell Biol. (2017) 95:347-55. doi: 10.1038/icb.2017.6

10. Spits H, Di Santo JP. The expanding family of innate lymphoid cells: regulators and effectors of immunity and tissue remodeling. Nat Immunol. (2011) 12:21-7. doi: 10.1038/ni.1962

11. Spits H, Artis D, Colonna M, Diefenbach A, Di Santo JP, Eberl G, et al. Innate lymphoid cells-a proposal for uniform nomenclature. Nat Rev Immunol. (2013) 13:145-9. doi: 10.1038/nri3365

12. Spits H, Bernink JH, Lanier L. NK cells and type 1 innate lymphoid cells: partners in host defense. Nat Immunol. (2016) 17:758-64. doi: 10.1038/ni.3482

13. Garside $\mathrm{P}$, Millington $\mathrm{O}$, Smith $\mathrm{K}$. The anatomy of mucosal immune response. Ann N Y Acad Sci. (2004) 1029:9-15. doi: 10.1196/annals.1309.002 gut anatomy and CRC. RB, RV, and DC wrote the cytokines crosstalk, gut anatomy and CRC. NF wrote microbioma and endocrine influence on innate immunity, some mechanisms of antibacteria immune response. MRZ wrote the section on autoimmune diseases such as Chron Disease and Ulcerative Colitis. FT wrote the section on exosomes.

\section{FUNDING}

This work was partially supported by the $5 \times 10002014$ and $5 \times 10002015$ from the Italian Ministry of Health to AP, the Italian Ministry of Health RF-2013, GR-2013-02356568 to RV and the AIRC (Associazione Italiana per la Ricerca sul Cancro) IG 2018 Id.21648.

\section{ACKNOWLEDGMENTS}

The figures have been assembled using some modified slides of Servier Medical Art at the web site: https://smart.servier.com.

14. Neutra M, Mantis N, Kraehenbuhl J. Collaboration of epithelial cells with organized mucosal lymphoid tissues. Nat Immunol. (2001) 2:10049. doi: 10.1038/ni1101-1004

15. Timonen T, Ortaldo JP, Herberman R. Characteristics of human large granular lymphocytes and relationship to natural killer and K cells. J Exp Med. (1981) 153:569-82.

16. Deniz G, van der Veen W, Akdis M. Natural killer cells in patients with allergic diseases. J Allergy Clin Immunol. (2013) 132:527-35. doi: 10.1016/j.jaci.2013.07.030

17. Vivier E, Tomasello E, Baratin M, Walzer T, Ugolini S. Functions of natural killer cells. Nat Immunol. (2008) 9:503-10. doi: 10.1038/ni1582

18. Farag S, Fehniger T, Ruggeri L, Velardi A, Caligiuri M. Natural killer cell receptors: new biology and insights into graft-versus-leukemia effect. Blood. (2002) 100:1935-47. doi: 10.1182/blood-2002-02-0350

19. Vivier E, Nunès J, Vèly F. Natural killer cell signaling pathways. Science. (2004) 306:1517-9. doi: 10.1126/science.1103478

20. Tallerico R, Garofalo C, Carbone E. A new biological feature of natural killer cells: the recognition of solid tumor-derived cancer stem cells. Front Immunol. (2016) 7:179. doi: 10.3389/fimmu.2016.00179

21. Corridoni D, Chapman T, Ambrose T, Simmons A. Emerging mechanisms of innate immunity and their translational potential in inflammatory bowel disease. Front Med. (2018) 5:32. doi: 10.3389/fmed.2018.00032

22. Gianchecchi E, Delfino DV, Fierabracci A. NK cells in autoimmune diseases: Linking innate and adaptive immune responses. Autoimmun Rev. (2018) 17:142-54. doi: 10.1016/j.autrev.2017.11.018

23. Coppola A, Arriga R, Lauro D, Del Principe MI, Buccisano F, Maurillo L, et al. NK cell inflammation in the clinical outcome of colorectal carcinoma. Front Med. (2015) 2:33. doi: 10.3389/fmed.2015.00033

24. Trinchieri G. Biology of natural killer cells. Adv Immunol. (1989) 47:187-376.

25. Hammer Q, Rückert T, Romagnani C. Natural killer cell specificity for viral infections. Nat Immunol. (2018)19:800-8. doi: 10.1038/s41590-018-0163-6

26. Cherrier DE, Serafini N, Di Santo JP. Innate lymphoid cell development: A $\mathrm{T}$ cell perspective. Immunity. (2018) 48:1091103. doi: 10.1016/j.immuni.2018.05.010

27. Morvan MG, Lanier LL. NK cells and cancer: you can teach innate cells new tricks. Nat Rev Cancer. (2016) 16:7-19. doi: 10.1038/nrc.2015.5

28. O'Sullivan TE, Sun JC, Lanier LL. Natural killer cell memory. Immunity. (2015) 43:634-45. doi: 10.1016/j.immuni.2015.09.013

29. Vacca P, Munari E, Tumino N, Moretta F, Pietra G, Vitale M, et al. Human Natural Killer cells and other innate lymphoid cells in cancer: friends or foes? Immunol Lett. (2018) 201:14-9. doi: 10.1016/j.imlet.2018. 11.004 
30. Moretta A, Bottino C, Vitale M, Pende D, Biassoni R, Mingari MC, et al. Receptors for HLA class-I molecules in human natural killer cells. Annu Rev Immunol. (1996)14:619-48. doi: 10.1146/annurev.immunol.14.1.619

31. Parham P, Moffett A. Variable NK cell receptors and their MHC class I ligands in immunity, reproduction and human evolution. Nat Rev Immunol. (2013) 13:133-44. doi: 10.1038/nri3370

32. Parham P. MHC class I molecules and KIRs in human history, health and survival. Nat Rev Immunol. (2005) 5:201-14. doi: 10.1038/nri1570

33. Robinette ML, Colonna M. Innate lymphoid cells and the MHC. HLA. (2016) 87:5-11. doi: 10.1111/tan.12723

34. Lim AI, Di Santo JP. ILC-poiesis: ensuring tissue ILC differentiation at the right place and time. Eur J Immunol. (2018) 49:118. doi: 10.1002/eji.201747294

35. Harly C, Cam M, Kaye J, Bhandoola A. Development and differentiation of early innate lymphoid progenitors. J Exp Med. (2018) 215:24962. doi: 10.1084 /jem. 20170832

36. Mjösberg J, Mazzurana L. ILC-poiesis: making tissue ILCs from blood. Immunity. (2017) 46:344-6. doi: 10.1016/j.immuni.2017.03.002

37. Sanos S, Diefenbach A. Isolation of NK cells and NK-like cells from the intestinal lamina propria. Methods Mol Biol. (2010) 612:50517. doi: 10.1007/978-1-60761-362-6_32

38. Leon F, Roldan E, Sanchez L, Camarero C, Bootello A, Roy G. Human small-intestinal epithelium contains functional natural killer lymphocytes. Gastroenterol. (2003) 125:345-56. doi: 10.1016/S0016-5085(03)00886-2

39. Lindgren A, Yun C, Lundgren A, Sjoling A, Ohman L, Svennerholm A, et al. $\mathrm{CD} 8^{-}$natural killer cells are greatly enriched in the human gastrointestinal tract and have the capacity to respond to bacteria. J Innate Immun. (2010) 2:294-302. doi: 10.1159/000286238

40. Satoh Takayama N, Vosshenrich C, Lesjean-Pottier S, Sawa S, Lochner M, Rattis $\mathrm{F}$ et al. Microbial flora drives interleukin 22 production in intestinal $\mathrm{NKp} 46^{+}$cells that provide innate mucosal immune defense. Immunity. (2008) 29:958-70. doi: 10.1016/j.immuni.2008.11.001

41. Luci C, Reynders A, Ivanov II, Cognet C, Chiche L, Chasson L, et al. Influence of the transcription factor RORgammat on the development of NKp46 ${ }^{+}$cell populations in gut and skin. Nature Immunol. (2010) 20:7582. doi: $10.1038 /$ ni. 1681

42. Sanos SL, Bui VL, Mortha A, Oberle K, Heners C, Johner C, et al. ROR $\gamma \mathrm{t}$ and commensal microflora are required for the differentiation of mucosal interleukin 22-producing NKp46 ${ }^{+}$cells. Nat Immunol. (2009) 10:83-91. doi: 10.1038/ni.1684

43. Eyerich K, Dimartino V, Cavani A. IL-17 and IL-22 in immunity: Driving protection and pathology. Eur J Immunol. (2017) 47:60714. doi: 10.1002/eji.201646723

44. Sips M, Sciaranghella G, Diefenbach T, Dugast AS, Berger CT, Liu Q, et al. Altered distribution of mucosal NK cells during HIV infection. Mucosal Immunol. (2012) 5:30-40. doi: 10.1038/mi.2011.40

45. Colonna M. Interleukin-22-producing natural killer cells and lymphoid tissue inducer-like cells in mucosal immunity. Immunity. (2009) 31:1523. doi: 10.1016/j.immuni.2009.06.008

46. Lopez-Vergès S, Milush JM, Pandey S, York VA, Arakawa-Hoyt J, Pircher $\mathrm{H}$, et al. CD57 defines a functionally distinct population of mature NK cells in the human CD56dim $\mathrm{CD}_{16}{ }^{+}$NK-cell subset. Blood. 116:386574. doi: 10.1182/blood-2010-04-282301

47. Mayassi T, Jabri B. Human intraepithelial lymphocytes. Mucosal Immunol. (2018) 11:1281-9. doi: 10.1038/s41385-018-0016-5

48. Montalban-Arques A, Chaparro M, Gisbert JP, Bernardo D. The innate immune system in the gastrointestinal tract: role of intraepithelial lymphocytes and lamina propria innate lymphoid cells in intestinal inflammation. Inflamm Bowel Dis. (2018) 24:1649-59. doi: 10.1093/ibd/izy177

49. Messina V, Buccione C, Marotta G, Ziccheddu G, Signore M, Mattia G, et al. Gut mesenchymal stromal cells in immunity. Stem Cells Int. (2017) 2017:8482326. doi: 10.1155/2017/8482326

50. Haffen K, Kedinger M, Simon-Assmann P. Mesenchyme-dependent differentiation of epithelial progenitor cells in the gut. J Pediatr Gastroenterol Nutr. (1987) 6:14-23.

51. Peaudecerf L, Rocha B. Role of the gut as a primary lymphoid organ. Immunol Lett. (2011) 140:1-6. doi: 10.1016/j.imlet.2011.05.009
52. Olivares-Villagómez D, Van Kaer L. Intestinal intraepithelial lymphocytes: sentinels of the mucosal barrier. Trends Immunol. (2018) 39:26475. doi: 10.1016/j.it.2017.11.003

53. Reboldi A, Cyster JG. Peyer's patches: organizing B-cell responses at the intestinal frontier. Immunol Rev. (2016) 271:230-45. doi: 10.1111/imr.12400

54. Tanoue T, Atarashi K, Honda K. Development and maintenance of intestinal regulatory $\mathrm{T}$ cells. Nat Rev Immunol. (2016) 16:295-309. doi: 10.1038/nri.2016.36

55. Mabbott NA, Donaldson DS, Ohno H, Williams IR, Mahajan A. Microfold (M) cells: important immunosurveillance posts in the intestinal epithelium. Mucosal Immunol. (2013) 6:666-77. doi: 10.1038/mi.2013.30

56. McGee JO'D, Isaacson PG, Wright NA. Oxford Textbook of Pathology, 2nd Edn. Oxford: Oxford University Press (1992).

57. Buettner M, Lochner M. Development and function of secondary and tertiary lymphoid organs in the small intestine and the colon. Front Immunol. (2016) 7:342. doi: 10.3389/fimmu.2016.00342

58. Dustin ML, Springer TA. Role of lymphocyte adhesion receptors in transient interactions and cell locomotion. Annu Rev Immunol. (1991) 9:27-66. doi: 10.1146/annurev.iy.09.040191.000331

59. Muller WA. Transendothelial migration: unifying principles from the endothelial perspective. Immunol Rev. (2016) 273:6175. doi: 10.1111/imr.12443

60. Nourshargh S, Alon R. Leukocyte migration into inflamed tissues. Immunity. (2014) 41:694-707. doi: 10.1016/j.immuni.2014.10.008

61. Lee M, Kiefel H, LaJevic MD, Macauley MS, Kawashima H, O’Hara E, et al. Transcriptional programs of lymphoid tissue capillary and high endothelium reveal control mechanisms for lymphocyte homing. Nat Immunol. (2014) 15:982-95. doi: 10.1038/ni.2983

62. Buffone A Jr, Anderson NR, Hammer DA. Migration against the direction of flow is LFA-1-dependent in human hematopoietic stem and progenitor cells. J Cell Sci. (2018) 131:jcs205575. doi: 10.1242/jcs.205575

63. Peng H, Tian Z. NK cell trafficking in health and autoimmunity: a comprehensive review. Clin Rev Allergy Immunol. (2014) 47:11927. doi: 10.1007/s12016-013-8400-0

64. Berahovich RD, Lai NL, Wei Z, Lanier LL, Schall TJ. Evidence for NKcell subsets based on chemokine receptor expression. J Immunol. (2006) 177:7833-40. doi: 10.4049/jimmunol.177.11.7833

65. Lima M, Leander M, Santos M, Santos AH, Lau C, Queirós ML, et al. Chemokine receptor expression on normal blood CD56(+) NK-cells elucidates cell partners that comigrate during the innate and adaptive immune responses and identifies a transitional NK-Cell population. Immunol Res. (2015) 2015:839684. doi: 10.1155/2015/839684

66. Campbell JJ, Qin S, Unutmaz D, Soler D, Murphy KE, Hodge MR, et al. Unique subpopulations of CD56+ NK and NK-T peripheral blood lymphocytes identified by chemokine receptor expression repertoire. $J$ Immunol. (2001) 166:6477-82. doi: 10.4049/jimmunol.166.11.6477

67. Lanier LL, Chang C, Phillips JH. Human NKR-P1A. A disulfide-linked homodimer of the C-type lectin superfamily expressed by a subset of NK and T lymphocytes. J Immunol. (1994) 153:2417-28.

68. Poggi A, Costa P, Morelli L, Cantoni C, Pella N, Spada F, et al. Expression of human NKRP1A by CD34+ immature thymocytes: NKRP1A-mediated regulation of proliferation and cytolytic activity. Eur J Immunol. (1996) 26:1266-72. doi: 10.1002/eji.1830260613

69. Llibre A, Garner L, Partridge A, Freeman GJ, Klenerman P, Willberg CB. Expression of lectin-like transcript-1 in human tissues. F1000Res. (2016) 5:2929. doi: 10.12688/f1000research.10009

70. Poggi A, Costa P, Zocchi MR, Moretta L. Phenotypic and functional analysis of $\mathrm{CD}^{+}{ }^{+} \mathrm{NKRP}_{1} \mathrm{~A}^{+}$human $\mathrm{T}$ lymphocytes. Direct evidence that the NKRP1A molecule is involved in transendothelial migration. Eur J Immunol. (1997) 27:2345-50. doi: 10.1002/eji.1830270932

71. Zocchi MR, Bottino C, Ferrini S, Moretta L, Moretta A. A novel 120-kD surface antigen expressed by a subset of human lymphocytes. Evidence that lymphokine-activated killer cells express this molecule and use it in their effector function. J Exp Med. (1987) 166:319-26.

72. Zocchi MR, Ferrero E, Leone BE, Rovere P, Bianchi E, Toninelli $\mathrm{E}$ et al. CD31/PECAM-1-driven chemokine-independent transmigration of human $\mathrm{T}$ lymphocytes. Eur J Immunol. (1996) 26:759-67. doi: 10.1002/eji.1830260406 
73. Ferrero E, Ferrero ME, Pardi R, Zocchi MR. The platelet endothelial cell adhesion molecule-1 (PECAM1) contributes to endothelial barrier function. FEBS Lett. (1995) 374:323-6.

74. Lertkiatmongkol P, Liao D, Mei H, Hu Y, Newman PJ. Endothelial functions of platelet/endothelial cell adhesion molecule-1 (CD31). Curr Opin Hematol. (2016) 23:253-9. doi: 10.1097/MOH.0000000000000239

75. Bernardini G, Antonangeli F, Bonanni V, Santoni A. Dysregulation of chemokine/chemokine receptor axes and NK cell tissue localization during diseases. Front Immunol. (2016) 7:402. doi: 10.3389/fimmu.2016.00402

76. Halama N, Braun M, Kahlert C, Spille A, Quack C, Rahbari N, et al. Natural killer cells are scarce in colorectal carcinoma tissue despite high levels of chemokines and cytokines. Clin Cancer Res. (2011) 17:67889. doi: 10.1158/1078-0432.CCR-10-2173

77. Park JH, Kotani T, Konno T, Setiawan J, Kitamura Y, Imada S, et al. Promotion of intestinal epithelial cell turnover by commensal bacteria: role of short-chain fatty acids. PLoS ONE. (2016) 11:e0156334. doi: 10.1371/journal.pone.0156334

78. Okada T, Fukuda S, Hase K, Nishiumi S, Izumi Y, Yoshida $\mathrm{M}$, et al. Microbiota-derived lactate accelerates colon epithelial cell turnover in starvation-refed mice. Nat Commun. (2013) 4:1654. doi: $10.1038 /$ ncomms 2668

79. Bevins CL, Salzman NH. Paneth cells, antimicrobial peptides and maintenance of intestinal homeostasis. Nat Rev Microbiol. (2011) 9:35668. doi: $10.1038 /$ nrmicro2546

80. Propheter DC, Chara AL, Harris TA, Ruhn KA, Hooper LV. Resistin-like molecule $\beta$ is a bactericidal protein that promotes spatial segregation of the microbiota and the colonic epithelium. Proc Natl Acad Sci USA. (2017) 114:11027-33. doi: 10.1073/pnas.1711395114

81. Bergström JH, Birchenough GM, Katona G, Schroeder BO, Schütte A, Ermund A, et al. Gram-positive bacteria are held at a distance in the colon mucus by the lectin-like protein ZG16. Proc Natl Acad Sci USA. (2016) 113:13833-8. doi: 10.1073/pnas.1611400113

82. McClure R, Massari P. TLR-dependent human mucosal epithelial cell responses to microbial pathogens. Front Immunol. (2014) 5:386. doi: 10.3389/fimmu.2014.00386

83. Frosali S, Pagliari D, Gambassi G, Landolfi R, Pandolfi F, Cianci R. How the intricate interaction among toll-like receptors, microbiota, and intestinal immunity can influence gastrointestinal pathology. J Immunol Res. (2015) 2015:489821. doi: 10.1155/2015/489821

84. Lee J, Mo JH, Katakura K, Alkalay I, Rucker AN, Liu YT, et al. Maintenance of colonic homeostasis by distinctive apical TLR9 signalling in intestinal epithelial cells. Nat Cell Biol. (2006) 8:1327-36. doi: 10.1038/ncb1500

85. Loke P, Cadwell K. Getting a taste for parasites in the gut. Immunity. (2018) 49:16-8. doi: 10.1016/j.immuni.2018.07.002

86. Mankertz J, Tavalali S, Schmitz H, Mankertz A, Riecken EO, Fromm M, et al. Expression from the human occludin promoter is affected by tumor necrosis factor alpha and interferon gamma. J Cell Sci. (2000) 113:2085-90.

87. Daig R, Rogler G, Aschenbrenner E, Vogl D, Falk W, Gross V, et al. Human intestinal epithelial cells secrete interleukin-1 receptor antagonist and interleukin-8 but not interleukin-1 or interleukin-6. Gut. (2000) 46:3508. doi: 10.1136/gut.46.3.350

88. Zeuthen LH, Fink LN, Frokiaer H. Epithelial cells prime the immune response to an array of gut-derived commensals towards a tolerogenic phenotype through distinct actions of thymic stromal lymphopoietin and transforming growth factor-beta. Immunology. (2008) 123:197208. doi: 10.1111/j.1365-2567.2007.02687.x

89. Gustot T, Lemmers A, Louis E, Nicaise C, Quertinmont E, Belaiche J, et al. Profile of soluble cytokine receptors in Crohn's disease. Gut. (2005) 54:488-95. doi: 10.1136/gut.2004.043554

90. Latorre E, Layunta E, Grasa L, Pardo J, García S, Alcalde AI, et al. Toll-like receptors 2 and 4 modulate intestinal IL-10 differently in ileum and colon. United Eur Gastroenterol J. (2018) 6:446-53. doi: 10.1177/20506406177 27180

91. Madsen KL, Malfair D, Gray D, Doyle JS, Jewell LD, Fedorak RN. Interleukin10 gene-deficient mice develop a primary intestinal permeability defect in response to enteric microflora. Inflamm Bowel Dis. (1999) 5:262-70.
92. Kominsky DJ, Campbell EL, Ehrentraut SF, Wilson KE, Kelly CJ, Glover LE, et al. IFN- $\gamma$-mediated induction of an apical IL10 receptor on polarized intestinal epithelia. J Immunol. (2014) 192:1267-76. doi: 10.4049/jimmunol.1301757

93. Takayama T, Kamada N, Chinen H, Okamoto S, Kitazume MT, Chang J, et al. Imbalance of NKp44(+)NKp46(-) and NKp44()NKp46(+) natural killer cells in the intestinal mucosa of patients with Crohn's disease. Gastroenterology. (2010) 139:882-92, 892.e1-3. doi: 10.1053/j.gastro.2010.05.040

94. Rutz S, Eidenschenk C, Ouyang W. IL-22, not simply a Th17 cytokine. Immunol Rev. (2013) 252:116-32. doi: 10.1111/imr.12027

95. Zheng Y, Valdez PA, Danilenko DM, Hu Y, Sa SM, Gong Q, et al. Interleukin22 mediates early host defense against attaching and effacing bacterial pathogens. Nat Med. (2008) 14:282-9. doi: 10.1038/nm1720

96. Pickard JM, Maurice CF, Kinnebrew MA, Abt MC, Schenten D, Golovkina TV, et al. Rapid fucosylation of intestinal epithelium sustains host-commensal symbiosis in sickness. Nature. (2014) 514:638-41. doi: 10.1038/nature13823

97. Sugimoto K, Ogawa A, Mizoguchi E, Shimomura Y, Andoh A, Bhan AK, et al. IL-22 ameliorates intestinal inflammation in a mouse model of ulcerative colitis. J Clin Invest. (2008) 118:534-44. doi: 10.1172/JCI33194

98. Sonnenberg GF, Monticelli LA, Alenghat T, Fung TC, Hutnick NA, Kunisawa J, et al. Innate lymphoid cells promote anatomical containment of lymphoid-resident commensal bacteria. Science. (2012) 336:13215. doi: 10.1126/science.1222551

99. Pickert G, Neufert C, Leppkes M, Zheng Y, Wittkopf N, Warntjen M, et al. STAT3 links IL-22 signaling in intestinal epithelial cells to mucosal wound healing. J Exp Med. (2009) 206:1465-72. doi: 10.1084/jem.20082683

100. Lindemans CA, Calafiore M, Mertelsmann AM, O'Connor MH, Dudakov JA, Jenq RR, et al. Interleukin-22 promotes intestinal-stem-cell-mediated epithelial regeneration. Nature. (2015) 528:560-4. doi: 10.1038/nature16460

101. Guglani L, Khader SA. Th17 cytokines in mucosal immunity and inflammation. Curr Opin HIV AIDS. (2010) 5:1207. doi: 10.1097/COH.0b013e328335c2f6

102. Blaschitz C, Raffatellu M. Th17 cytokines and the gut mucosal barrier. J Clin Immunol. (2010) 30:196-203. doi: 10.1007/s10875-010-9368-7

103. Bregenholt S, Berche P, Brombacher F, di SantoJP. Conventional alpha beta $\mathrm{T}$ cells are sufficient for innate and adaptive immunity against enteric Listeria monocytogenes. J Immunol. (2001) 166:1871-6. doi: 10.4049/jimmunol.166.3.1871

104. Naper C, Shegarfi H, Inngjerdingen M, Rolstad B. The role of natural killer cells in the defense against Listeria monocytogenes lessons from a rat model. J Innate Immunity. (2011) 3:289-97. doi: 10.1159/000324143

105. Ashkar AA, Reid S, Verdu EF, Zhang K, Coombes BK. Interleukin-15 and NK1.1+ cells provide innate protection against acute Salmonella enteric aserovar typhimurium infection in the gut and in systemic tissues. Infect Immun. (2009)77:214-22. doi: 10.1128/IAI.01066-08

106. Hall LJ, Murphy CT, Hurley G Quinlan A, Shanahan F, Nally K, et al. Natural killer cells protect against mucosal and systemic infection with the enteric pathogen citrobacter rodentium. Infect Immun. (2013) 81:4609. doi: 10.1128/IAI.00953-12

107. Sotolongo J, España C, Echeverry A, Siefker D, Altman N, Zaias J, et al. Host innate recognition of an intestinal bacterial pathogen induces TRIF dependent protective immunity. J Exp Med. (2011) 208:270516. doi: 10.1084/jem.20110547

108. Gensollen T, Iyer SS, Kasper DL, Blumberg RS. How colonization by microbiota in early life shapes the immune system. Science. (2016) 352:53944. doi: 10.1126/science.aad9378

109. Souza-Fonseca-Guimaraes F, Parlato M, Philippart F, Misset B, Cavaillon JM, Adib Conquy M. Toll-like receptors expression and interferon-c production by NK cells in human sepsis. Crit Care. (2012) 16:R206. doi: 10.1186/cc11838

110. Guo Y, Patil NK, Luan L, Bohannon JK, Sherwood ER. The biology of natural killer cells during sepsis Immunology. 153, 190-202. doi: 10.1111/imm.12854

111. Martin MP, Gao X, Lee JH, Nelson GW, Detels R, Goedert JJ, et al. Epistatic interaction between KIR3DS1 and HLA-B delays the progression to AIDS. Nat Genet. (2002) 31:429-34. doi: 10.1038/ng934 
112. Martin MP, Qi Y, Gao X, Yamada E, Martin JN, Pereyra F, et al. Innate partnership of HLA-B and KIR3DL1 subtypes against HIV-1. Nat Genet. (2007) 39:733-40. doi: 10.1038/ng2035

113. Halme L, Loginov R, Arola J, Turunen U, Lautenschlager I. HHV-6 antigen and HHV-6 DNA expression in sporadic adenomatous polyps of the colon. Scand J Gastroenterol. (2013) 48:1423-7. doi: 10.3109/00365521.2013. 843200

114. Schmiedel D, Tai J, Levi-Schaffer F, Dovrat S, Mandelboim O. Human herpesvirus $6 \mathrm{~B}$ downregulates expression of activating ligands during lytic infection to escape elimination by natural killer cells. J Virol. (2016) 90:960817. doi: 10.1128/JVI.01164-16

115. Brandt CS, Baratin M, Yi EC, Kennedy J, Gao Z, Fox B, et al. The B7 family member B7-H6 is a tumor cell ligand for the activating natural killer cell receptor NKp30 in humans. J ExpMed. (2009) 206:1495503. doi: 10.1084/jem.20090681

116. Eliassen E, Di Luca D, Rizzo R, Barao I. The Interplay between Natural Killer Cells and Human Herpesvirus-6. Viruses. (2017) 9:E367. doi: 10.3390/v9120367

117. . Round JL, Mazmanian SK. The gut microbiota shapes intestinal immune responses during health and disease. Nat Rev Immunol. (2009) 9:31323. doi: $10.1038 /$ nri2515

118. Wu HJ, Wu E. The role of gut microbiota in immune homeostasis and autoimmunity. Gut Microbes. (2012) 3:4-14. doi: 10.4161/gmic.19320

119. Maslowski KM, Mackay CR. Diet, gut microbiota and immune responses. Nat Immunol. (2011) 12:5-9. doi: 10.1038/ni0111-5

120. Corrêa-Oliveira R, Fachi JL, Vieira A, Sato FT, Vinolo MA. Regulation of immune cell function by short-chain fatty acids. Clin Transl Immunol. (2016) 5:e73. doi: 10.1038/cti.2016.17

121. Gonçalves P, Araújo JR, Di Santo JP. A cross-talk between microbiotaderived short-chain fatty acids and the host mucosal immune system regulates intestinal homeostasis and inflammatory bowel disease. Inflamm Bowel Dis. (2018) 24:558-72 doi: 10.1093/ibd/izx029

122. Akira S, Takeda K, Kaisho T. Toll-like receptors: critical proteins linking innate and acquired immunity. Nat Immunol. (2001) 2:67580. doi: $10.1038 / 90609$

123. Fong FL, Shah NP, Kirjavainen P, El-Nezami H. Mechanism of action of probiotic bacteria on intestinal and systemic immunities and antigen-presenting cells. Int Rev Immunol. (2016) 35:179-88. doi: 10.3109/08830185.2015.1096937

124. Pessi T, Sütas Y, Hurme M, Isolauri E. Interleukin-10 generation in atopic children following oral Lactobacillus rhamnosus GG. Clin Exp Allergy. (2000) 30:1804-8. doi: 10.1046/j.1365-2222.2000.00948.x

125. Steed H, Macfarlane GT, Blackett KL, Bahrami B, Reynolds N, Walsh SV, et al. Clinical trial: the microbiological and immunological effects of synbiotic consumption - a randomized double-blind placebo-controlled study in active Crohn's disease. Aliment Pharmacol Ther. (2010) 32:87283. doi: 10.1111/j.1365-2036.2010.04417.x

126. Qiu Y, Jiang Z, Hu S, Wang L, Ma X, Yang X. Lactobacillus plantarum enhanced IL-22 production in Natural Killer (NK) cells that protect the integrity of intestinal epithelial cell barrier damaged by enterotoxigenic Escherichia coli. Int J Mol Sci. (2017) 18:E2409. doi: 10.3390/ijms18112409

127. Suzuki T. Regulation of intestinal epithelial permeability by tight junctions. Cell Mol Life Sci. (2013) 70:631-59. doi: 10.1007/s00018-012-1070-x

128. Horinaka M, Yoshida T, Kishi A, Akatani K, Yasuda T, Kouhara $\mathrm{J}$, et al. Lactobacillus strains induce TRAIL production and facilitate natural killer activity against cancer cells. FEBS Lett. (2010) 584:57782. doi: 10.1016/j.febslet.2009.12.004

129. Costabile A, Bergillos-Meca T, Rasinkangas P, Korpela K, de Vos WM, Gibson GR. Effects of soluble corn fiber alone or in synbiotic combination with Lactobacillus rhamnosus GG and the pilus-deficient derivative GG-PB12 on fecal microbiota, metabolism, and markers of immune function: a randomized, double-blind, placebo-controlled, crossover study in healthy elderly (Saimes Study). Front Immunol. (2017) 8:1443. doi: 10.3389/fimmu.2017.01443

130. Sierra S, Lara-Villoslada F, Sempere L, Olivares M, Boza J, Xaus J. Intestinal and immunological effects of daily oral administration of Lactobacillus salivarius CECT5713 to healthy adults. Anaerobe. (2010) 16:195-200. doi: 10.1016/j.anaerobe.2010.02.001
131. Khan WI, Ghia JE. Gut hormones: emerging role in immune activation and inflammation. Clin Exp Immunol. (2010) 161:19-27. doi: 10.1111/j.1365-2249.2010.04150.x

132. Kidd M, Gustafsson BI, Drozdov I, Modlin IM. ILlbeta- and LPS-induced serotonin secretion is increased in EC cells derived from Crohn's disease. Neurogastroenterol Motil. (2009) 21:439-50. doi: $10.1111 /$ j.1365-2982.2008.01210.x

133. Wang H, Steeds J, Motomura Y, Deng Y, Verma-Gandhu M, El-Sharkawy RT, et al. CD4+ T cell-mediated immunological control of enterochromaffin cell hyperplasia and 5-hydroxytryptamine production in enteric infection. Gut. (2007) 56: 949-57. doi: 10.1136/gut.2006.103226

134. Geremia A, Biancheri P, Allan P, Corazza GR, Di Sabatino A. Innate and adaptive immunity in inflammatory bowel disease. Autoimmun Rev. (2014) 13:3-10. doi: 10.1016/j.autrev.2013.06.004

135. Baumgart DC, Carding SR. Inflammatory bowel disease: cause and immunobiology. Lancet. (2007) 369:162740. doi: 10.1016/S0140-6736(07)60750-8

136. Muro M, López-Hernández R, Mrowiec A. Immunogenetic biomarkers in inflammatory bowel diseases: role of the IBD3 region. World J Gastroenterol. (2014) 20:15037-48. doi: 10.3748/wjg.v20.i41.15037

137. Kmiec Z, Cyman M, Slenioda TJ. Cell of the innate and adaptive immunity and their interactions in inflammatory bowel disease. Adv Med Sci. (2017) 62:1-16. doi: 10.1016/j.advms.2016.09.001

138. Eken A, Singh AK, Oukka M. Interleukin 23 in Crohn's disease. Inflamm Bowel Dis. (2014) 20:587-95. doi: 10.1097/01.MIB.0000442014.52661.20

139. Britton S, Eklund AE, Bird AG. Appearance of killer (K) cells in the mesenteric lymph nodes in Crohn's disease. Gastroenterology. (1978) 75:218-20.

140. Fathollahi A, Aslani S, Mostafaei S, Rezaei N, Mahmoudi M. The role of killer-cell immunoglobulin-like receptor (KIR) genes in susceptibility to inflammatory bowel disease: systematic review and meta-analysis. Inflamm Res. (2018) 67:727-36. doi: 10.1007/s00011-018-1162-7

141. Cella M, Fuchs A, VermiW, Facchetti F, Otero K, Lennerz JK, et al. A human natural killer cell subset provides an innate source of IL-22 for mucosal immunity. Nature. (2009) 457:722-5. doi: 10.1038/nature07537

142. Díaz-Peña R, Vidal-Castiñeira JR, Moro-García MA, Alonso-Arias R, Castro-Santos P. Significant association of the KIR2DL3/HLA-C1 genotype with susceptibility to Crohn's disease. Hum Immunol. (2016) 77:1049. doi: 10.1016/j.humimm.2015.10.020

143. Lin L, Ma C, Wei B, Aziz N, Rajalingam R, Yusung S, et al. Human NK cells licensed by killer Ig receptor genes have an altered cytokine program that modifies CD4+ T cell function. J Immunol. (2014) 193:9409. doi: 10.4049/jimmunol.1400093

144. Fitzpatrick LR. Inhibition of IL-17 as a pharmacological approach for IBD. Int Rev Immunol. (2013) 32:544-55. doi: 10.3109/08830185.2013.821118

145. Patel DD, Lee DM, Kolbinger F, Antoni C. Effect of IL-17A blockade with secukinumab in autoimmune diseases. Ann Rheum Dis. (2013) 72(Suppl. 2):ii116-23. doi: 10.1136/annrheumdis-2012-202371

146. Hohenberger M, Cardwell LA, Oussedik E, Feldman SR Interleukin-17 inhibition: role in psoriasis and inflammatory bowel diseases. J Dermatolog Treat. (2018) 29:13-8. doi: 10.1080/09546634.2017.1329511

147. Ito H. Treatment of Crohn's disease with anti-IL-6 receptor antibody. $J$ Gastroenterol. (2005) 40(Suppl. 16):32-4.

148. Wright EK, Ding NS, Niewiadomski O. Management of inflammatory bowel disease. Med J Aust. (2018) 209:318-23. doi: 10.5694/mja17.01001

149. Geremia A, Jewel DP. The IL-23/IL-17 pathway in inflammatory bowel disease. Expert Rev Gastroenterol Hepatol. (2012) 6:223-37. doi: 10.1586/egh.11.107

150. Settesoldi A, Coppola M, Rogai F, Annese V. Ustekinumab: moving the target from psoriasis to Crohn's disease. Expert Rev Gastroenterol Hepatol. (2014) 8:5-13. doi: 10.1586/17474124.2014.850414

151. Perera L, Shao L, Patel A, Evans K, Meresse B, Blumberg R, et al. Expression of nonclassical class I molecules by intestinal epithelial cells. Inflamm Bowel Dis. (2007) 13:298-307. doi: 10.1002/ibd.20026

152. Vadstrup K, Bendtsen F. Anti-NKG2D mAb: a new treatment for Crohn's disease? Int J Mol Sci. (2017) 18:E1997. doi: 10.3390/ijms18091997

153. Espinoza JL, Minami M. Sensing bacterial-induced DNA damaging effects via natural killer group 2 member $D$ immune receptor: from 
dysbiosis to autoimmunity and carcinogenesis. Front Immunol. (2018) 9:52. doi: 10.3389/fimmu.2018.00052

154. Allez $M$, Skolnick BE, Wisniewska-Jarosinska M, Petryka R, Overgaard RV. Anti-NKG2D monoclonal antibody (NNC0142-0002) in active Crohn's disease: a randomised controlled trial. Gut. (2017) 66:1918-25. doi: 10.1136/gutjnl-2016-311824

155. Targan SR, Karp LC. Defects in mucosal immunity leading to ulcerative colitis. Immunol Rev. (2005) 206:296305. doi: 10.1111/j.0105-2896.2005.00286.x

156. Tatiya-Aphiradee N, Chatuphonprasert W, Jarukamjorn K. Immune response and inflammatory pathway of ulcerative colitis. J Basic Clin Physiol Pharmacol. (2018) 30:1-10. doi: 10.1515/jbcpp-2018-0036

157. Fuss IJ, Strober W. The role of IL-13 and NK T cells in experimental and human ulcerative colitis. Mucosal Immunol. (2008) 1(Suppl. 1):S313. doi: $10.1038 / \mathrm{mi} .2008 .40$

158. Mannon PJ, Hornung RL, Yang Z, Yi C, Groden C, Friend J, et al. Suppression of inflammation in ulcerative colitis by interferon- $\beta-1 \mathrm{a}$ is accompanied by inhibition of IL-13 production. Gut. (2011) 60:44955. doi: $10.1136 /$ gut.2010.226860

159. Jones DC, Edgar RS, Ahmad T, Cummings JR, Jewell DP, Trowsdale $J$, et al. Killer Ig-like receptor (KIR) genotype and HLA ligand combinations in ulcerative colitis susceptibility. Genes Immun. (2006) 7:57682. doi: $10.1038 /$ sj.gene.6364333

160. Wang F, Peng PL, Lin X, Chang Y, Liu J, Zhou R, et al. Regulatory role of NKG2D+ NK cells in intestinal lamina propria by secreting doubleedged Th1 cytokines in ulcerative colitis. Oncotarget. (2017) 8:9894552. doi: 10.18632/oncotarget.22132

161. Yusung S, McGovern D, Lin L, Hommes D, Lagishetty V, Braun J. NK cells are biologic and biochemical targets of 6-mercaptopurine in Crohn's disease patients. Clin Immunol. (2017) 175:82-90. doi: 10.1016/j.clim.2016.12.004

162. Guinney J, Dienstmann R, Wang X, de Reyniès A, Schlicker A, Soneson C, et al. The consensus molecular subtypes of colorectal cancer. Nat Med. (2015) 21:1350-6. doi: 10.1038/nm.3967

163. Boland PM, Ma WW. Immunotherapy for colorectal cancer. Cancers. (2017) 9:E50. doi: 10.3390/cancers9050050

164. Tauriello DVF, Batlle E. Targeting the microenvironment in advanced colorectal cancer. Trends Cancer. (2016) 2:495504. doi: 10.1016/j.trecan.2016.08.001

165. Costa D, Venè R, Benelli R, Romairone E, Scabini S, Catellani S, et al. Targeting the epidermal growth factor receptor can counteract the inhibition of natural killer cell function exerted by colorectal tumor-associated fibroblasts. Front Immunol. (2018) 9:1150. doi: 10.3389/fimmu.2018.01150

166. Sandel MH, Speetjens FM, Menon AG, Albertsson PA, Basse $\mathrm{PH}$, Hokland $\mathrm{M}$, et al. Natural killer cells infiltrating colorectal cancer and MHC class I expression. Mol Immunol. (2005) 42:541-6. doi: 10.1016/j.molimm.2004.07.039

167. Tallerico R, Todaro M, Di Franco S, Maccalli C, Garofalo C, Sottile R, et al. Human NK cells selective targeting of colon cancer-initiating cells: a role for natural cytotoxicity receptors and MHC class I molecules. J Immunol. (2013) 190:2381-90. doi: 10.4049/jimmunol.1201542

168. Sconocchia G, Eppenberger S, Spagnoli GC, Tornillo L, Droeser $\mathrm{R}$, Caratelli $\mathrm{S}$, et al. NK cells and $\mathrm{T}$ cells cooperate during the clinical course of colorectal cancer. Oncoimmunology. (2014) 3:e952197. doi: 10.4161/21624011.2014.952197

169. Ottaiano A, Napolitano M, Capozzi M, Tafuto S, Avallone A, Scala S. Natural killer cells activity in a metastatic colorectal cancer patient with complete and long lasting response to therapy. World J Clin Cases. (2017) 5:390-6. doi: 10.12998/wjcc.v5.i11.390

170. Zhang Z, Su T, He L, Wang H, Ji G, Liu X, et al. Identification and functional analysis of ligands for natural killer cell activating receptors in colon carcinoma. Tohoku J Exp Med. (2012) 226:59-68. doi: 10.6120/tjem.226.59

171. McGilvray RW, Eagle RA, Watson NF, Al-Attar A, Ball G, Jafferji I, et al. NKG2D ligand expression in human colorectal cancer reveals associations with prognosis and evidence for immunoediting. Clin Cancer Res. (2009) 15:6993-7002. doi: 10.1158/1078-0432.CCR-09-0991

172. Canossi A, Aureli A, Del Beato T, Rossi P, Franceschilli L, De Sanctis F, et al. Role of KIR and CD16A genotypes in colorectal carcinoma genetic risk and clinical stage. J Transl Med. (2016) 14:239. doi: 10.1186/s12967-016-1001-y
173. Portela P, Merzoni J, Lindenau JD, Damin DC, Wilson TJ, Roesler $\mathrm{R}$, et al. KIR genes and HLA class I ligands in a Caucasian Brazilian population with colorectal cancer. Hum Immunol. (2017) 78:263-8. doi: 10.1016/j.humimm.2017.01.003

174. Danillo GA. The impact of KIR polymorphism on the risk of developing cancer: not as strong as imagined? Front Genet. (2016) 7:121. doi: $10.3389 /$ fgene.2016.00121

175. Adachi T, Hinoi T, Hattori M, Egi H, Shimomura M, Saito Y, et al. The modified Glasgow prognostic score for early mortality in patients with synchronous peritoneal carcinomatosis from colorectal cancer. Surg Today. (2015) 45:1396-403. doi: 10.1007/s00595-014-1080-4

176. Mlecnik B, Bindea G, Angell HK, Sasso MS, Obenauf AC, Fredriksen T, et al. Functional network pipeline reveals genetic determinants associated with in situ lymphocyte proliferation and survival of cancer patients. Sci Transl Med. (2014) 6:228ra37. doi: 10.1126/scitranslmed.3007240

177. Mager LF, Wasmer MH, Rau TT, Krebs P. Cytokine-induced modulation of colorectal cancer. Front Oncol. (2016) 6:96. doi: 10.3389/fonc.2016. 00096

178. Chaix J, Tessmer MS, Hoebe K, Fuséri N, Ryffel B, Dalod M, et al. Cutting edge: priming of NK cells by IL-18. J Immunol. (2008) 181:1627-31. doi: 10.4049/jimmunol.181.3.162

179. Srivastava S, Pelloso D, Feng H, Voiles L, Lewis D, Haskova Z, et al. Effects of interleukin-18 on natural killer cells: costimulation of activation through Fc receptors for immunoglobulin. Cancer Immunol Immunother. (2013) 62:1073-82. doi: 10.1007/s00262-013-1403-0

180. Sun D, Lin Y, Hong J, Chen H, Nagarsheth N, Peng D, et al. Th22 cells control colon tumorigenesis through STAT3 and Polycomb Repression complex 2 signaling. Oncoimmunology. (2015) 5:e1082704. doi: 10.1080/2162402X.2015.1082704

181. Wu T, Wang Z, Liu Y, Mei Z, Wang G, Liang Z, et al. Interleukin 22 protects colorectal cancer cells from chemotherapy by activating the STAT3 pathway and inducing autocrine expression of interleukin 8. Clin Immunol. (2014) 154:116-26. doi: 10.1016/j.clim.2014.07.005

182. Wu T, Cui L, Liang Z, Liu C, Liu Y, Li J. Elevated serum IL-22 levels correlate with chemoresistant condition of colorectal cancer. Clin Immunol. (2013) 147:38-9. doi: 10.1016/j.clim.2013.02.007

183. Oppmann B, Lesley R, Blom B, Timans JC, Xu Y, Hunte B, et al. Novel p19 protein engages IL-12p40 to form a cytokine, IL-23, with biological activities similar as well as distinct from IL-12. Immunity. (2000) 13:71525. doi: 10.1016/S1074-7613(00)00070-4

184. Chognard G, Bellemare L, Pelletier AN, Dominguez-Punaro MC, Beauchamp C, Guyon MJ, et al. The dichotomous pattern of IL-12r and IL-23R expression elucidates the role of IL-12 and IL-23 in inflammation. PLoS ONE. (2014) 9:e89092. doi: 10.1371/journal.pone.0089092

185. Michielsen AJ, Ryan EJ, O'Sullivan JN. Dendritic cell inhibition correlates with survival of colorectal cancer patients on bevacizumab treatment. Oncoimmunology. (2012) 1:1445-7. doi: 10.4161/onci.21318

186. Zhang L, Li J, Li L, Zhang J, Wang X, Yang C, et al. IL-23 selectively promotes the metastasis of colorectal carcinoma cells with impaired Socs3 expression via the STAT5 pathway. Carcinogenesis. (2014) 35:133040. doi: 10.1093/carcin/bgu017

187. Cui G, Yuan A, Goll R, Florholmen J. IL-17A in the tumor microenvironment of the human colorectal adenomacarcinoma sequence. Scand J Gastroenterol. (2012) 47:130412. doi: $10.3109 / 00365521.2012 .725089$

188. Bindea G, Mlecnik B, Tosolini M, Kirilovsky A, Waldner M, Obenauf AC, et al. Spatiotemporal dynamics of intratumoral immune cells reveal the immune landscape in human cancer. Immunity. (2013) 39:78295. doi: 10.1016/j.immuni.2013.10.003

189. Tosolini M, Kirilovsky A, Mlecnik B, Fredriksen T, Mauger S, Bindea G, et al. Clinical impact of different classes of infiltrating $\mathrm{T}$ cytotoxic and helper cells (Th1, Th2, Treg, Th17) in patients with colorectal cancer. Cancer Res. (2011) 71:1263-71. doi: 10.1158/0008-5472.CAN-10-2907

190. Amicarella F, Muraro MG, Hirt C, Cremonesi E, Padovan E, Mele V, et al. Dual role of tumour-infiltrating T helper 17 cells in human colorectal cancer. Gut. (2017) 66:692-704. doi: 10.1136/gutjnl-2015-310016

191. Al Obeed OA, Vaali-Mohamed MA, Alkhayal KA, Bin Traiki TA, Zubaidi AM, Arafah M, et al. IL-17 and colorectal cancer risk in the Middle East: 
gene polymorphisms and expression. Cancer Manag Res. (2018) 10:265361. doi: 10.2147/CMAR.S161248

192. Zheng X, Chen F, Zhang Q, Liu Y, You P, Sun S, et al. Salivary exosomal PSMA7: a promising biomarker of inflammatory bowel disease. Protein Cell. (2017) 8:686-95. doi: 10.1007/s13238-017-0413-7

193. Colombo M, Raposo G, Théry C. Biogenesis, secretion, and intercellular interactions of exosomes and other extracellular vesicles. Annu Rev Cell Dev Biol. (2014) 30:255-89. doi: 10.1146/annurev-cellbio-101512-122326

194. Hessvik NP, Llorente A. Current knowledge on exosome biogenesis and release. Cell Mol Life Sci. (2018) 75:193-208. doi: 10.1007/s00018-017-2595-9

195. Morton AM, Sefik E, Upadhyay R, Weissleder R, Benoist C, Mathis D. Endoscopic photoconversion reveals unexpectedly broad leukocyte trafficking to and from the gut. Proc Natl Acad Sci USA. (2014) 111:6696701. doi: 10.1073/pnas.1405634111

196. Smythies LE, Smythies JR. Exosomes in the gut. Front Immunol. (2014) 5:104. doi: 10.3389/fimmu.2014.00104

197. Bui TM, Mascarenhas LA, Sumagin R. Extracellular vesicles regulate immune responses and cellular function in intestinal inflammation and repair. Tissue Barriers. (2018) 6:e1431038. doi: 10.1080/21688370.2018.1431038

198. Zhang H, Deng T, Liu R, Bai M, Zhou L, Wang X, et al. Exosome-delivered EGFR regulates liver microenvironment to promote gastric cancer liver metastasis. Nat Commun. (2017) 8:15016. doi: 10.1038/ncomms15016

199. Reiners KS, Dassler J, Coch C, Pogge von Strandmann E. Role of exosomes released by dendritic cells and/or by tumor targets: regulation of NK cell plasticity. Front Immunol. (2014) 5:91. doi: 10.3389/fimmu.2014.00091

200. Viaud S, Terme M, Flament C, Taieb J, Andre F, Novault S, et al. Dendritic cell-derived exosomes promote natural killer cell activation and proliferation: a rolefor NKG2Dligands and IL-15Ralpha. PLoS ONE. (2009) 4:e4942. doi: 10.1371/journal.pone.0004942

201. Simhadri VR, Reiners KS, Hansen HP, Topolar D, Simhadri VL, Nohroudi K, et al. Dendritic cells release HLA-B-associated transcript-3 positive exosomes to regulate natural killer function. PLoS ONE. (2008) 3:e3377. doi: 10.1371/journal.pone.0003377

202. Chen X, Song CH, Feng BS, Li TL, Li P, Zheng PY, et al. Intestinal epithelial cell-derived integrin $\alpha \beta 6$ plays an important role in the induction of regulatory $\mathrm{T}$ cells and inhibits an antigen-specific Th2 response. J Leukoc Biol. (2011) 90:751-9. doi: 10.1189/jlb.1210696

203. Hickman-Miller HD, Hildebrand WH. The immune response under stress: the role of HSP-derived peptides. Trends Immunol. (2004) 25:42733. doi: 10.1016/j.it.2004.05.011

204. Gastpar R, Gehrmann M, Bausero MA, Asea A, Gross C, Schroeder JA, et al. Heat shock protein 70 surface-positive tumor exosomes stimulate migratory and cytolytic activity of natural killer cells. Cancer Res. (2005) 65:5238-47. doi: 10.1158/0008-5472.CAN-04-3804

205. Lv LH, Wan YL, Lin Y, Zhang W, Yang M, Li GL, et al. Anticancer drugs cause release of exosomes with heat shock proteins from human hepatocellular carcinoma cells that elicit effective natural killer cell antitumor responses in vitro. J Biol Chem. (2012) 287:15874-85. doi: 10.1074/jbc.M112.340588
206. vanNiel G, Raposo G, Candalh C, Boussac M, Hershberg R, CerfBensussan $\mathrm{N}$, et al. Intestinal epithelial cells secrete exosome-like vesicles. Gastroenterology. (2001) 121:337-49. doi: 10.1053/gast.2001.26263

207. Deng ZB, Zhuang X, Ju S, Xiang X, Mu J, Liu Y, et al. Exosomes-like nanoparticles from intestinal mucosal cells carry prostaglandin E2 and suppress activation of liver natural killer T cells. J Immunol. (2013) 190: 3579-89. doi: 10.4049/jimmunol.1203170

208. Besse B, Charrier M, Lapierre V, Dansin E, Lantz O, Planchard D, et al. Dendritic cell-derived exosomes as maintenance immunotherapy after first line chemotherapy in NSCLC. Oncoimmunology. (2016) 5:e1071008. doi: 10.1080/2162402X.2015.1071008

209. Lugini L, Cecchetti S, Huber V, Luciani F, Macchia G, Spadaro F, et al. Immune surveillance properties of human NK cell-derived exosomes. $J$ Immunol. (2012) 189:2833-42. doi: 10.4049/jimmunol.1101988

210. Fais S. NK cell-released exosomes: natural nanobullets against tumors. Oncoimmunology. (2013) 2:e22337. doi: 10.4161/onci.22337

211. Jong AY, Wu CH, Li J, Sun J, Fabbri M, Wayne AS, et al. Largescale isolation and cytotoxicity of extracellular vesicles derived from activated human natural killer cells. J Extracell Vesicles. (2017) 6:1294368. doi: 10.1080/20013078.2017.1294368

212. ClinicalTrials.gov Identifier: NCT03422120. Human Blood Specimen Collection to Evaluate Immune Cell Function. Rebecca C Auer, MD. Ottawa Hospital. Available online at: https://clinicaltrials.gov/ct2/show/ NCT03422120?term $=$ Natural\$+\$killer\$+\$AND \$ $\$$ natural $\$+\$$ killer $\$+\$$ $\% 28 \mathrm{NK} \% 29 \$+\$$ cells\&rank=4

213. Cruz-Acuña R, Quirós M, Farkas AE, Dedhia PH, Huang S, Siuda D, et al. Synthetic hydrogels for human intestinal organoid generation and colonic wound repair. Nat Cell Biol. (2017) 19:1326-35. doi: 10.1038/ ncb3632

214. Kim SH, Chi M, Yi B, Kim SH, Oh S, Kim Y, et al. Three-dimensional intestinal villi epithelium enhances protection of human intestinal cells from bacterial infection by inducing mucin expression. Integr Biol. (2014). 6:1122-31. doi: 10.1039/c4ib00157e

215. Zhang YS, Duchamp M, Oklu R, Ellisen LW, Langer R, Khademhosseini A. Bioprinting the cancer microenvironment. ACS Biomater Sci Eng. (2016) 2:1710-21. doi: 10.1021/acsbiomaterials.6b00246

Conflict of Interest Statement: The authors declare that the research was conducted in the absence of any commercial or financial relationships that could be construed as a potential conflict of interest.

Copyright (C) 2019 Poggi, Benelli, Venè, Costa, Ferrari, Tosetti and Zocchi. This is an open-access article distributed under the terms of the Creative Commons Attribution License (CC BY). The use, distribution or reproduction in other forums is permitted, provided the original author(s) and the copyright owner(s) are credited and that the original publication in this journal is cited, in accordance with accepted academic practice. No use, distribution or reproduction is permitted which does not comply with these terms. 